Prepared in cooperation with the Osage Nation

\title{
Geologic and Geophysical Models for Osage County, Oklahoma, with Implications for Groundwater Resources
}

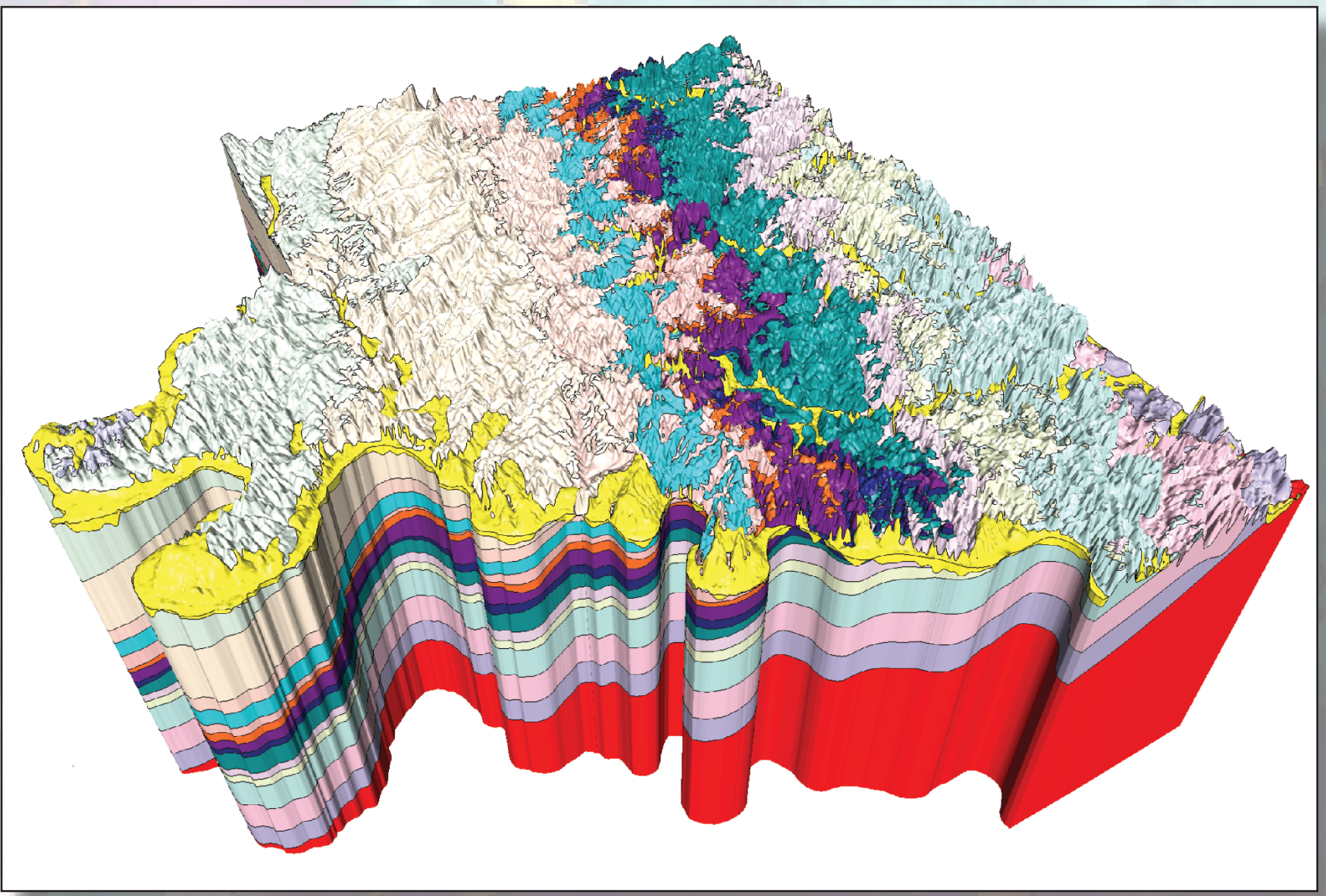

Scientific Investigations Report 2016-5067 
Cover. Three-dimensional (3-D) geologic model for Osage County, looking to the northeast with 30× vertical exaggeration, showing perspective view of full model. 


\section{Geologic and Geophysical Models for Osage County, Oklahoma, with Implications for Groundwater Resources}

By Mark R. Hudson, David V. Smith, Michael P. Pantea, and Carol J. Becker

Prepared in cooperation with the Osage Nation

Scientific Investigations Report 2016-5067 


\title{
U.S. Department of the Interior SALLY JEWELL, Secretary
}

\section{U.S. Geological Survey Suzette M. Kimball, Director}

\author{
U.S. Geological Survey, Reston, Virginia: 2016
}

For more information on the USGS - the Federal source for science about the Earth, its natural and living resources, natural hazards, and the environment—visit http://www.usgs.gov or call 1-888-ASK-USGS.

For an overview of USGS information products, including maps, imagery, and publications, visit http://store.usgs.gov.

Any use of trade, firm, or product names is for descriptive purposes only and does not imply endorsement by the U.S. Government.

Although this information product, for the most part, is in the public domain, it also may contain copyrighted materials as noted in the text. Permission to reproduce copyrighted items must be secured from the copyright owner.

Suggested citation:

Hudson, M.R., Smith, D.V., Pantea, M.P., and Becker, C.J., 2016, Geologic and geophysical models for Osage County, Oklahoma, and implications for groundwater resources: U.S. Geological Survey Scientific Investigations Report 2016 5067, 27 p., http://dx.doi.org/10.3133/sir20165067.

ISSN 2328-0328 (online) 


\section{Acknowledgments}

This study was completed in cooperation with the Osage Nation and was carried out as part of a larger U.S. Geological Survey (USGS) project to assess the water resources of Osage County, Okla. Jason Masoner and Derek Ryter of the USGS provided valuable discussions on water resources and hydrogeologic units in Osage County. Christopher Kunkel of the USGS provided able help with identification and compilation of depths to stratigraphic horizons on paper wire-line log cross sections. This report benefited from technical reviews by Shana Mashburn and Ronald Drake of the USGS. A thorough review of geologic names by Nancy Stamm and Julie Herrick (both of USGS) provided an updated summary of stratigraphic nomenclature and ages for Lower Permian and Upper Pennsylvanian strata of Osage County. 



\section{Contents}

Acknowledgments ……...................................................................................................................

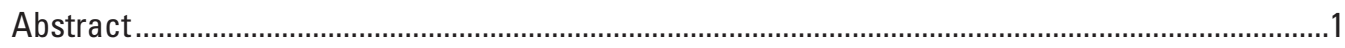

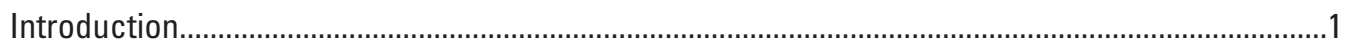

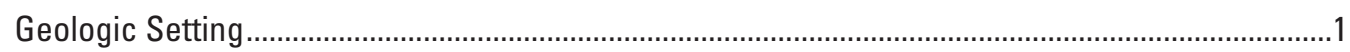

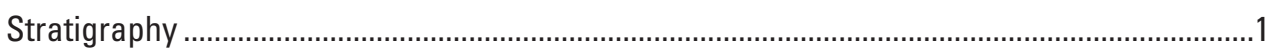

Structure

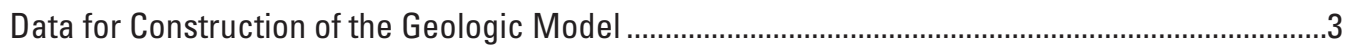

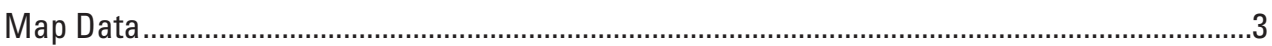

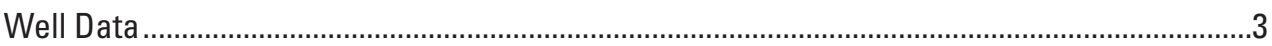

Wire-Line Geophysical Logs and Unit Identifications .......................................................

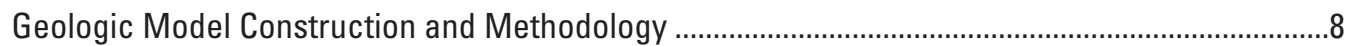

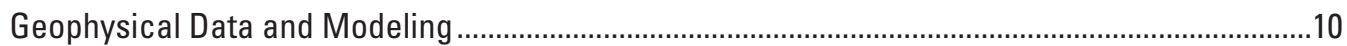

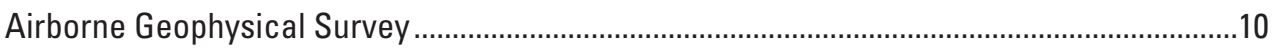

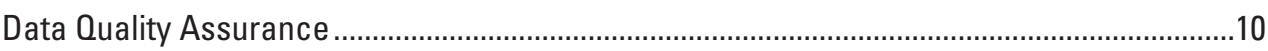

Development of Electrical Resistivity Cross Sections ...........................................................12

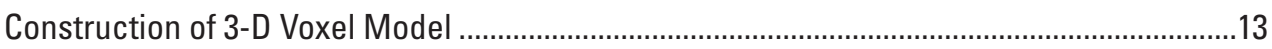

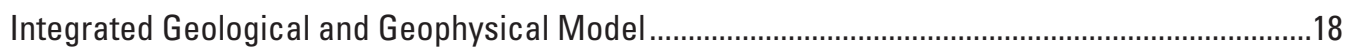

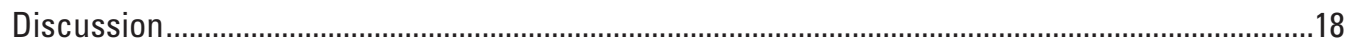

Correlations Between Geology and AEM Results...........................................................18

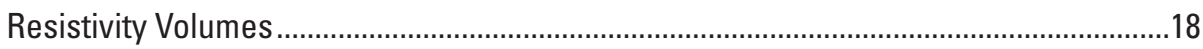

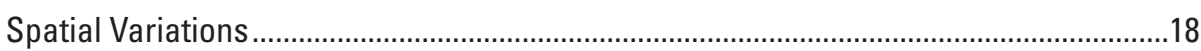

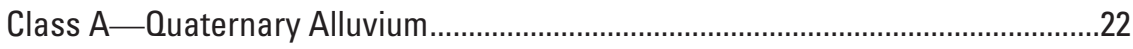

Class B —Elgin Sandstone Lentil........................................................................22

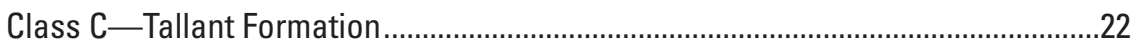

Class D-Combined Wann, Iola, Chanute Formations ..............................................22

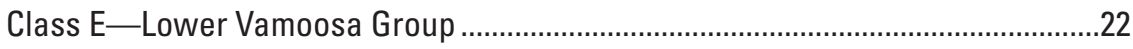

Class F-Upper Vanoss Group ...........................................................................22

Comparison of Electrical Resistivity to Depth to Potable Water Estimates ....................22

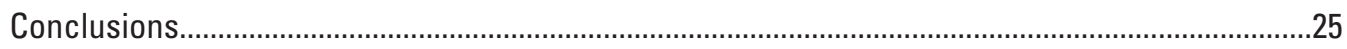

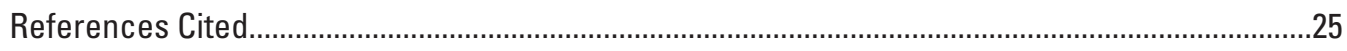

Appendix

\section{Figures}

1. The broad geologic divisions of Bigham and Bergman (1980) were followed. Geologic map of Osage County (modified from Andrews and Smith, 2014), with tectonic setting inset

2. General names and subdivisions of rock units exposed at the surface in Osage County that were used for construction of the geologic model, including subdivisions of the Vamoosa-Ada aquifer

3. Maps showing the spatial distribution of wells with subsurface horizons in Upper Pennsylvanian strata identified in wire-line geophysical logs used in construction of the three-dimensional (3-D) geologic model for Osage County 
4. Example of wire-line log from northwestern Osage County (see figure 3) digitized from the Cole cross sections (Boyd, 2011) showing selected horizons ("picks") of stratigraphic units and regional marker beds.

5. Images of three-dimensional (3-D) geologic model for Osage County, looking to the northeast with $30 \times$ vertical exaggeration. $A$, Perspective view of full model. $B$, Top of Checkerboard_Ls model layer, with distribution of supporting well control data. $C$, Chair cut illustrating down-dip projections of geologic model layers.

6. A, Index map showing airborne electromagnetic survey flight lines in which flight lines for the reconnaissance. $B$, Primary (blue), secondary (green), and tertiary (orange) section lines overlie topographic surface projections of the Wellington_Fm, Ada_Grp, Vamoosa_lower, and Coffeyville_Fm.

7. A, Curtain fence diagram of a gridded resistivity cross-section for flight line L10080, revealing layered geology. $B$, Stacked fence diagram of all reconnaissance survey flight lines...

8. A, Map of inverted resistivity at a depth of $100 \mathrm{~m}$ below ground surface. $B$, Map of inverted resistivity at an elevation of $250 \mathrm{~m}$. Blank areas occur where the fixed elevation dips below the depth of investigation..

9. $A$, Three-dimensional model created from the primary and synthetic flight lines. $B$, Vertical slice along a constant $Y$ value. $C$, Horizontal slice along a constant $Z$ (elevation) value.

10. A, Earth resistivity section along flight-line L10060 with geologic model layers superimposed. B, Extract of the Vamoosa_lower geologic model layer resistivity section. $C$, Frequency histograms (green bars) of resistivity data within geologic model layer binned versus resistivity (right) and Easting (top)

11. Image of integrated geology-electrical resistivity model, all views looking downward to northeast with a $40 \times$ vertical exaggeration. $A$, Geologic layers cut to show westward dip and truncated at the limit of usable resistivity data. $B$, Same view as $A$ but displaying electrical resistivity variations embedded as model property. $C$, View of Elgin_Ss model layer from surface to depth of investigation showing electrical resistivity variations. $D$, Same as $C$ for Tallant_Fm model layer.

12. Resistivity volumes for geologic layers within the integrated geology-electrical resistivity model. $A$, Volumes of individual geologic model layers for the full resistivity range as well as for $10 \mathrm{ohm}-\mathrm{m}$ increments up to $50 \mathrm{ohm}-\mathrm{m}$ and the remaining higher resistivity values. $B$, Proportion of volume for resistivity increments relative to the full resistivity volume for geologic model layers. $C$, Proportion of volume for resistivity increments greater than $30 \mathrm{ohm}-\mathrm{m}$ relative to the full resistivity volume for geologic model layers.

13. A, Map view of integrated geology-resistivity model illustrating six (A-F) geologyelectrical resistivity classes. $B$, Vertical view of geologic layers with electrical resistivity $>30 \mathrm{ohm}-\mathrm{m}$ with overlain geology-electrical resistivity classes

14. Perspective views of the integrated geology-resistivity model and primary data line electrical resistivity values, both showing electrical resistivity $>30 \mathrm{ohm}-\mathrm{m}$, with enlarged insets of cross section segments. Geology-electrical resistivity classes of figure 13 are labeled. $A$, Northern section illustrating correlation of high-resistivity with Elgin_Ss model layer. Legends for electrical resistivity and geologic model layer pertain to all images. $B$, Central section illustrating correlation of high resistivity with higher Elgin_Ss layer and lower Tallant_Fm model layer. C, Southern section illustrating correlation of high electrical resistivity with lowest Wann_Iola_Chanute_Fms layer as well as higher layers. 
15. Base of potable water from D'Lugosz and others (1986) compared to integrated geology-resistivity model views. $A$, Map view of electrical resistivity as in figure $13 \mathrm{~A}$ with draped elevation contours ( $100 \mathrm{ft}$ contour interval) of base of potable water from D'Lugosz and others (1986), $B$, Northward perspective view of three-dimensional (3-D) model surface representing the base of the potable water with draped structure contours $C$, Southwestward perspective view showing a fence diagram of geologic model layers having a resistivity $>30 \mathrm{ohm}-\mathrm{m}$ that fills the eastern and northwestern potable water troughs

\section{Tables}

1. Summary of geologic units in Osage County, Oklahoma, and constraints used for construction of three-dimensional geologic model .................................................

2. Summary statistics for principal data channels ..............................................................12

3. Layered-earth model parameters for resistivity inversions ...........................................13

\section{Conversion Factors}

International System of Units to Inch/Pound

\begin{tabular}{lcl}
\hline \multicolumn{1}{c}{ Multiply } & By & To obtain \\
\hline centimeter $(\mathrm{cm})$ & Length & \\
millimeter $(\mathrm{mm})$ & 0.3937 & inch (in.) \\
meter $(\mathrm{m})$ & 0.03937 & inch (in.) \\
kilometer $(\mathrm{km})$ & 3.281 & foot (ft) \\
\hline & 0.6214 & mile (mi) \\
\hline square meter $\left(\mathrm{m}^{2}\right)$ & Area & square foot $\left(\mathrm{ft}^{2}\right)$ \\
square kilometer $\left(\mathrm{km}^{2}\right)$ & 10.76 & square mile $\left(\mathrm{mi}^{2}\right)$ \\
\hline & 0.3861 & \\
\hline cubic kilometer $\left(\mathrm{km}^{3}\right)$ & Volume & cubic mile (mi $\left.{ }^{3}\right)$ \\
cubic meter $\left(\mathrm{m}^{3}\right)$ & 0.2399 & acre-foot (acre- $\mathrm{ft})$ \\
liter $(\mathrm{L})$ & 0.0008107 & gallon (gal) \\
\hline & 0.2642 & \\
\hline gram $(\mathrm{g})$ & Mass & ounce, avoirdupois $(\mathrm{oz})$ \\
\hline
\end{tabular}

\section{Datum}

Models $\mathrm{X}$ and $\mathrm{Y}$ coordinates are Universal Transverse Mercator (UTM) Ellipsoid, Geodetic Reference System 1980 (GRS 80), North American Datum 1983 (NAD 83), zone 14 in meters; and $Z$ values are elevation in meters, North American Vertical Datum 1988 (NAVD 88).

Elevation, as used in this report, refers to distance above the vertical datum. 



\title{
Geologic and Geophysical Models for Osage County, Oklahoma, with Implications for Groundwater Resources
}

\author{
By Mark R. Hudson, David V. Smith, Michael P. Pantea, and Carol J. Becker
}

\section{Abstract}

This report summarizes a three-dimensional geologic model that was constructed to provide a framework to investigate groundwater resources of the Osage Nation in northeastern Oklahoma. This report also presents an analysis of an airborne electromagnetic survey that assessed the spatial variation of electrical resistivity to depths as great as 300 meters in the subsurface. The report and model provide support for a countywide assessment of groundwater resources, emphasizing the Upper Pennsylvanian rock units in the shallow subsurface of central and eastern Osage County having electrical resistivity properties that may indicate aquifers.

Surface outcrops and subsurface stratigraphic picks on wire-line geophysical logs of Upper Pennsylvanian-Lower Permian sedimentary rock were used to construct a threedimensional model of the geologic subsurface as an aid for evaluating groundwater resources in Osage County. Quaternary alluvium and terraces along major streams and the Arkansas River are included in the geologic framework model. Data from the AEM survey were subjected to quality-control procedures, truncated at depth of investigation, and then used to build a three-dimensional electrical resistivity model making use of secondary and tertiary interpolation profiles between primary data profiles. The AEM data highlight westward-inclined resistivity gradients that parallel the shallow dip of bedrock strata; bodies have resistivity $>30 \mathrm{ohm}$-meters and extend as much as 10 kilometers down the dip of host geologic units. Volume analysis and internal imaging of an integrated three-dimensional geology and electrical resistivity model give a proxy for likely aquifer units with large relative volumes of high resistivity: Quaternary alluvium, Elgin Sandstone Lentil in the upper part of the Vamoosa Group, Tallant Formation, and parts of a combined Wann-IolaChanute Formation. Less voluminous, high-resistivity bodies correspond to intervals in the lower part of the Vamoosa Group in the east-central part of the county and probable limestone intervals in the upper part of the Vanoss Group in the northwest part of the county. Northwestern and eastern troughs of potable water previously defined for central Osage County generally correspond to down-dip projections of high-resistivity bodies associated with the Elgin Sandstone Lentil of the Vamoosa Group and Tallant Formation, respectively.

\section{Introduction}

This report summarizes a three-dimensional (3-D) geologic model that was constructed to provide a framework to investigate the groundwater resources of the Osage Nation in Osage County in northeastern Oklahoma. This report also presents an analysis of an airborne electromagnetic (AEM) survey that was acquired to assess the spatial variation of electrical resistivity to depths as great as 300 meters (m) in the subsurface of Osage County. This report and model provide support for a countywide assessment of groundwater resources, emphasizing Upper Pennsylvanian rock strata in the shallow subsurface of central and eastern Osage County having electrical resistivity properties that may indicate aquifers.

\section{Geologic Setting}

Osage County is underlain by strata of the Oklahoma platform that lie between two uplifts, the Ozark dome and the Nemaha ridge, that were active during the late Paleozoic (Cole, 1969; fig. 1). Surface exposures of bedrock in Osage County consist of a series of north-northeast striking outcrop bands of Upper Pennsylvanian to Lower Permian sedimentary rocks that dip gently westward at less than 1 degree. Pennsylvanian strata are underlain at depth by strata of Mississippian, Late Devonian, Ordovician, and Cambrian age with an aggregate thickness of as much as 1,370 meter $(\mathrm{m})$ overlying Precambrian crystalline basement rocks (Beckwith, 1928). Quaternary alluvial deposits are preserved in major stream drainages of the county and locally are also preserved as older, higher terrace deposits adjacent to the Arkansas River.

\section{Stratigraphy}

Sedimentary rock units at the surface or shallow subsurface of Osage County are mostly interbedded shale, sandstone, and limestone sequences of Late Pennsylvanian to Early Permian age. The published nomenclature for rock units in Osage County is complicated in that it includes informal names that were used through a long history of hydrocarbon 


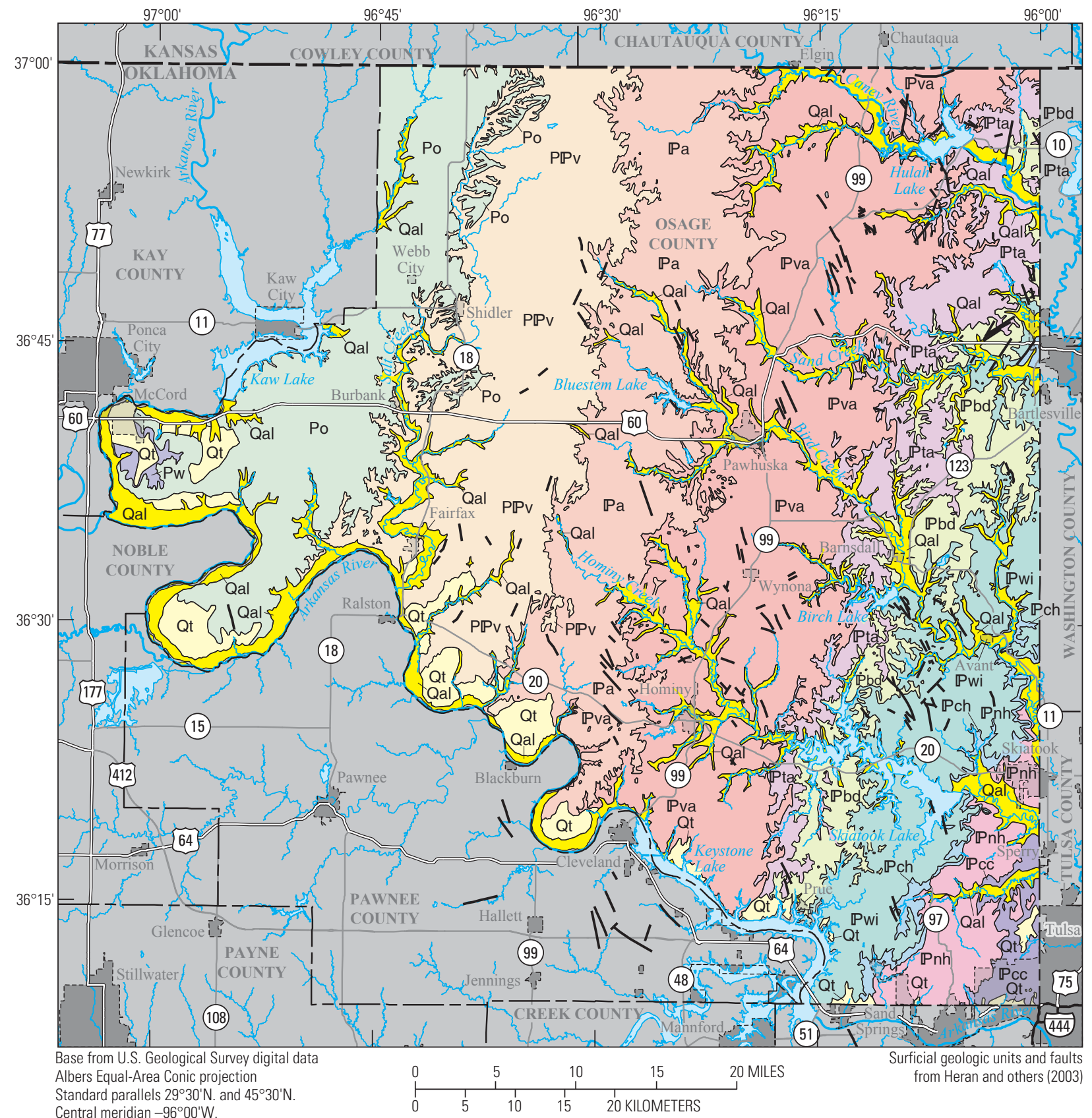

Central meridian $-96^{\circ} 00^{\prime} \mathrm{W}$.
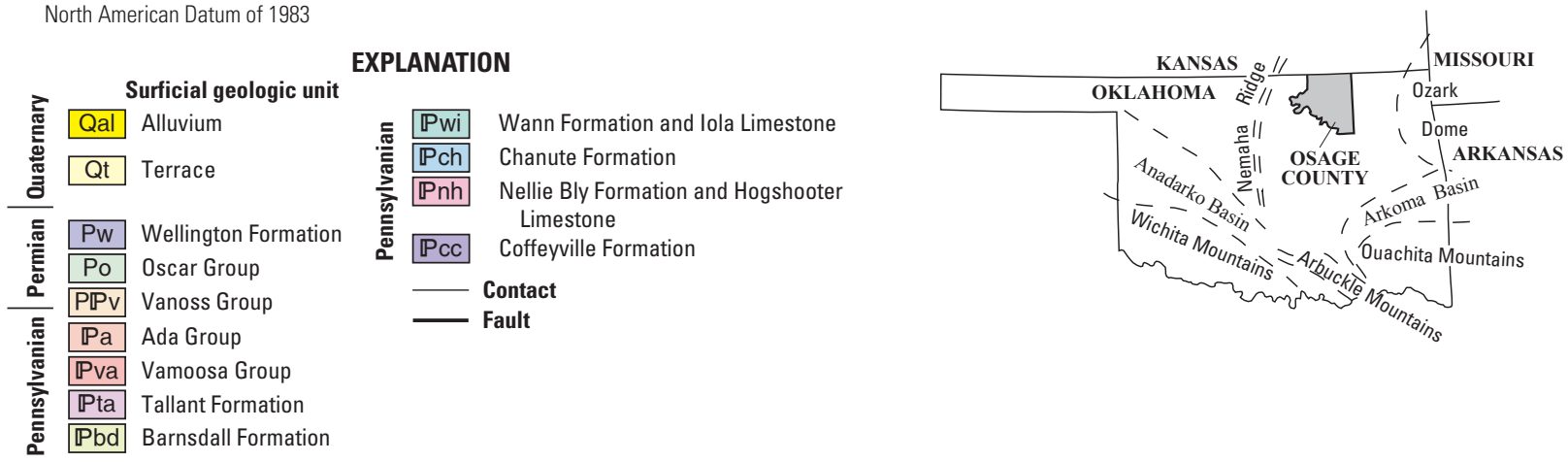

Figure 1. Geologic map of Osage County showing broad geologic divisions of Bingham and Bergman (1980). Modified from Andrews and Smith (2014), with tectonic setting inset. 
exploration and because sedimentary facies in the county can be transitional between those for type areas in central Oklahoma and southeastern Kansas (Branson, 1957; Shields, 1993). For the purpose of a countywide representation of the geology for a hydrogeologic framework, the broad geologic divisions of Bingham and Bergman (1980) were followed as shown on figure 1 with additional subunits or zones included in the Vamoosa-Ada aquifer that may contain or separate significant fresh groundwater resources. A stratigraphic column (fig. 2) modified from Abbott (2000) illustrates general names and subdivisions of rock units in the Vamoosa-Ada aquifer that were generally used for the geologic model, although the Bingham and Bergman (1980) stratigraphic designation of Ada and Vamoosa strata as group rather than formation is followed.

\section{Structure}

The structure of Osage County is that of a west-dipping monocline with bedrock formations deepening westward at an overall rate of about 7.6 meters per kilometer $(\mathrm{m} / \mathrm{km})$ (40 feet per mile ( $\mathrm{ft} / \mathrm{mi})$ ). Elongate zones containing open domal folds with low closure are superimposed on the monoclinal structure (Bass, 1942). North-northeast trending zones of small en echelon faults that have as much as $15 \mathrm{~m}$ of throw coincide with zones of domal folding. Foley (1926) and Marshak and others (2003) suggested that zones of en echelon faulting have a component of strike-slip offset and probably reactivated preexisting basement structural zones.

\section{Data for Construction of the Geologic Model}

A 3-D geologic model was constructed to represent the geologic framework for Osage County and to be used to superimpose results from geophysical analysis of the AEM survey for comparison. To construct the geologic model, information was used from surface geologic maps and wire-line geophysical logs from subsurface drill holes.

\section{Map Data}

Broad divisions of the geology were taken from the geologic map of Osage County (fig. 1) as presented by Bingham and Bergman (1980) and as represented in geographic information system (GIS) format by Heran and others (2003). Contact lines from the GIS map were registered to the U.S. Geological Survey (USGS) 10-m digital elevation model (DEM). For each $\mathrm{X}$ and $\mathrm{Y}$ coordinate of the contact, an elevation was obtained for the equivalent $\mathrm{X}$ and $\mathrm{Y}$ coordinate of the DEM. The contact surfaces were projected westward into the subsurface using stratigraphic dip and additional control provided by data from wire-line geophysical logs.

\section{Well Data}

A multitude of wells drilled for water, oil, and gas provide information about the subsurface distribution of the bedrock units in Osage County. Wire-line geophysical logs from drill holes were used for subsurface control and to determine depths to selected contacts of geologic units. Depths to selected geologic horizons (or 'picks') were determined from a series of small scale ( 1 in. $=100 \mathrm{ft})$ cross sections constructed by the late petroleum geologist Dr. J. Glenn Cole from the 1960s through the 1980s (Boyd, 2011). The Cole cross sections were made available to the public through efforts of the Tulsa Geological Society and Oklahoma City Geological Society as digital scans of original paper plates (Energy Libraries Online, 2015). The M-series cross sections (Boyd, 2011) include about 30 cross sections using about 1,450 wire-line geophysical logs constructed that run north-south and east-west across Osage County and include correlations for persistent marker beds based on Dr. Cole's long-term investigations of stratigraphy in northeastern Oklahoma, aiding identification and correlation of intervening units. For this study, depths to selected geologic unit contacts and marker beds were identified on the Cole cross sections and tabulated using spontaneous potential, gamma ray (when available), conductivity, and resistivity curves from as many as 236 wire-line geophysical logs spaced about 5 miles apart, or less where greater detail was needed (fig. 3). Additional wells could be added for site-specific studies, but that was beyond the scope of this study.

Most wells drilled for oil and gas in Osage County have steel surface casing set through the freshwater zones during the drilling process that prevented the collection of geophysical information through these zones. As a result, most wire-line logs lack useful information for shallow groundwater resources. Depths to potential aquifer units of interest were estimated by identifying them at deeper depths (beneath casing) and projecting their contacts up dip toward surface exposures.

To better define the thickness of the terrace and alluvial aquifers along the Arkansas River for the geologic model, depths to the base of the aquifer from 102 test holes were used (Mashburn and others, 2003).

\section{Wire-Line Geophysical Logs and Unit Identifications}

Unit identification for the geologic model was facilitated by type logs, such as are available for west-central Osage County in Johnson (1992). Well picks were made for eight horizons (H1 to H8, table 1; figs. 3 and 4) in the Upper Pennsylvanian stratigraphic section to add subsurface control for the surface geologic contacts and to divide the Vamoosa and Ada Groups into subunits to permit assessment of differing hydrogeologic properties in the Vamoosa-Ada aquifer. A series of limestone intervals interbedded with shale in the lower part of the Ada Group, the Pawhuska Formation of 


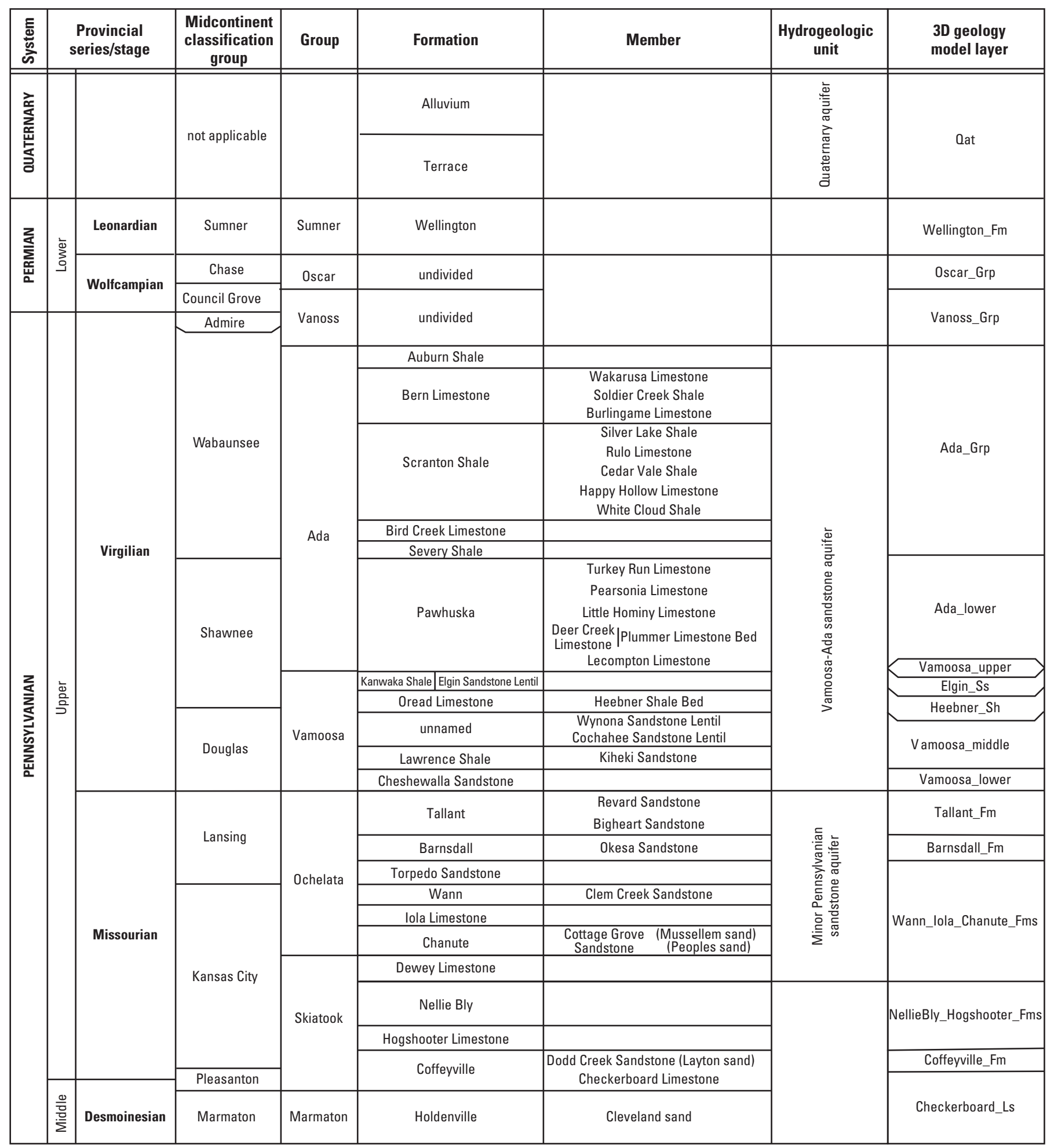

Figure 2. General names and subdivisions of rock units exposed at the surface in 0sage County that were used for construction of the geologic model, including subdivisions of the Vamoosa-Ada aquifer. The stratigraphic classification of Abbott (2000) was used and references therein updated from Fay (1997), Gentile and Thompson (2004), and Sawin and others (2006, 2008). Ss, Sandstone; Sh, Shale; Ls, Limestone 

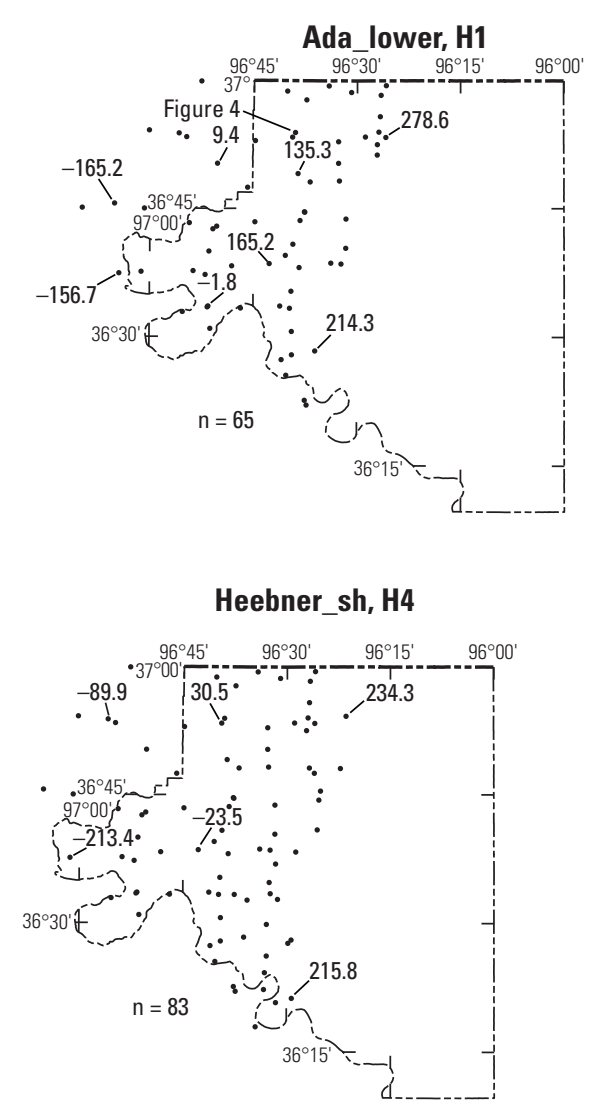
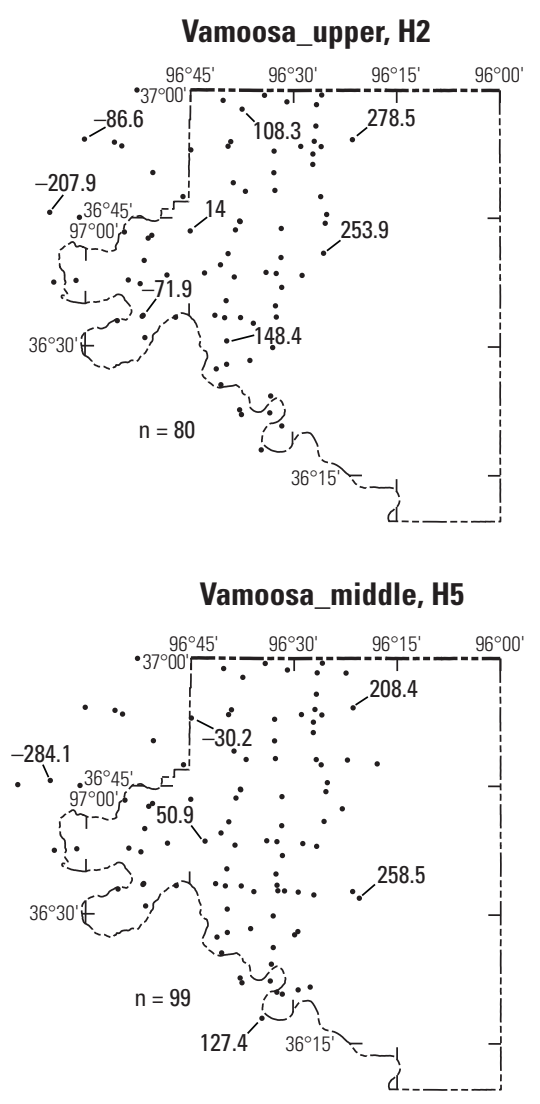
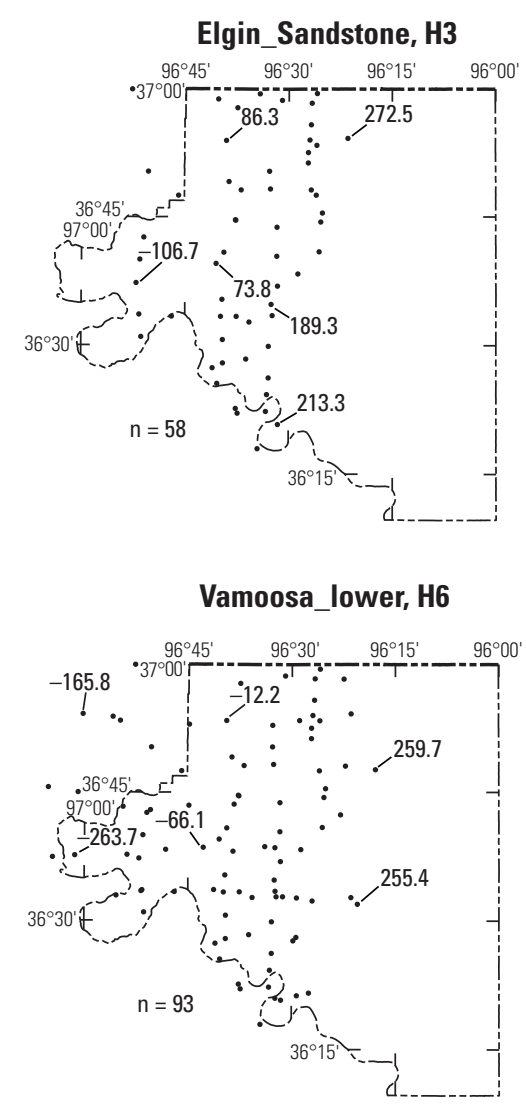

Barnsdall_Formation, H7

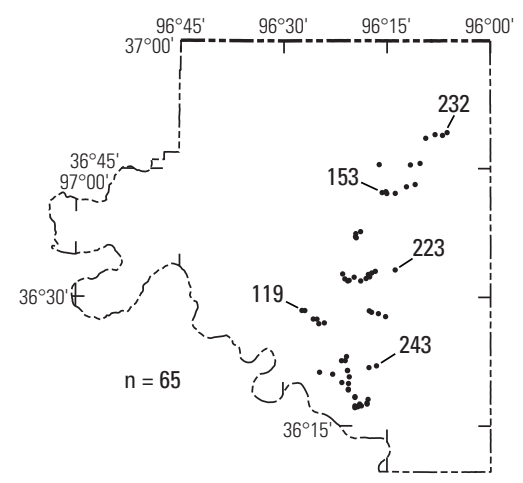

Universal Transverse Mercator projection Zone 14N
North American Datum 1983

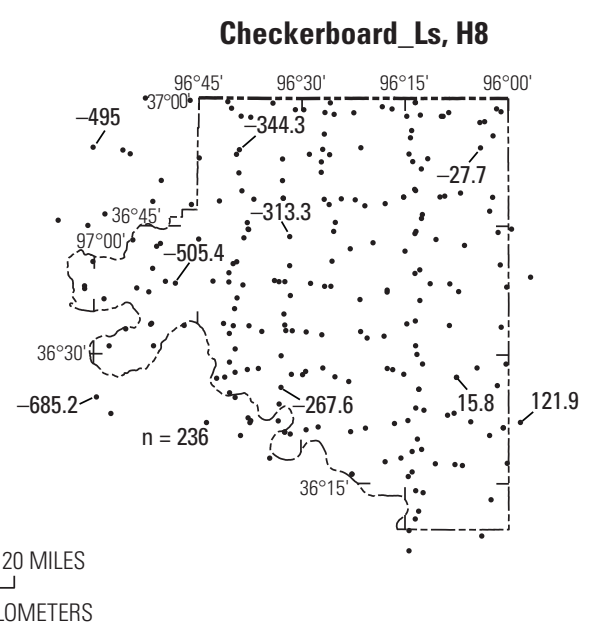

Checkerboard_Ls, H8

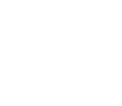

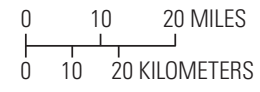

EXPLANATION

\footnotetext{
- Selected well

278.5 Well elevation-Elevation in meters

$\mathrm{n}$ Number of well picks
}

Figure 3. Maps showing the spatial distribution of wells with subsurface horizons in Upper Pennsylvanian strata identified in wireline geophysical logs used in construction of the three-dimensional (3-D) geologic model for Osage County. The general westward deepening of each of the eight horizons (table 1) is shown by elevations (in meters) labeled for selected wells. n, number of well picks. 
Table 1. Summary of geologic units in Osage County, Oklahoma, and constraints used for construction of three-dimensional geologic model.

[Symbol and map unit from Bingham and Bergman (1980); Subunit, subdivision of Ada and Vamoosa Groups used in this report; Unit contact, either base or top of designated unit; Horizon, well countcontact identified in wire-line geophysical logs and the number of well data used in development of corresponding geological model horizon; Comment, description of horizon; 3D model layer top, name used in geologic model; Control type, surface contact on geologic map of Bingham and Bergman (1980) or well pick from wire-line geophysical log; Reference horizon, unit used for reference in geologic modeling project; na, not available; Ss, sandstone; Ls, limestone; Fm, formation]

\begin{tabular}{|c|c|c|c|c|c|c|c|c|}
\hline Symbol & Map unit & Subunit & $\begin{array}{c}\text { Unit } \\
\text { contact }\end{array}$ & $\begin{array}{c}\text { Horizon, } \\
\text { well } \\
\text { count }\end{array}$ & Comment & 3D model layer & $\begin{array}{l}\text { Control } \\
\text { type }\end{array}$ & $\begin{array}{c}\text { Reference } \\
\text { horizon }\end{array}$ \\
\hline Qa, Qt & $\begin{array}{l}\text { Quaternary alluvium, } \\
\text { terrace }\end{array}$ & & Base & $\mathrm{H} 0,102$ & Test holes from Mashburn and others (2003) & Qat & $\begin{array}{l}\text { Map trace, } \\
\text { wells }\end{array}$ & None \\
\hline Pw & Wellington Formation & & na & & & Wellington_Fm & Map trace & Vamoosa_middle \\
\hline Po & Oscar Group & & Top & & & Oscar_Grp & Map trace & Vamoosa_middle \\
\hline PPv & Vanoss Group & & Top & & & Vanoss_Grp & Map trace & Vamoosa_middle \\
\hline \multirow[t]{2}{*}{$\mathrm{Pa}$} & Ada Group & & Top & & & Ada_Grp & Map trace & Vamoosa_middle \\
\hline & & Lower Ada & Top & $\mathrm{H} 1,65$ & Pick on top of limestone interval sequence & Ada_lower & Wells & Vamoosa_middle \\
\hline \multirow[t]{5}{*}{ Pva } & Vamoosa Group & & Top & $\mathrm{H} 2$, & Pick on bottom of limestone interval sequence & Vamoosa_upper & $\begin{array}{l}\text { Map trace, } \\
\text { wells }\end{array}$ & Vamoosa_middle \\
\hline & & Elgin Ss. Lentil & Top & $\mathrm{H} 3,58$ & Pick on top of sandstone & Elgin_Ss & Wells & Vamoosa_middle \\
\hline & & Elgin Ss. Lentil & Base & $\mathrm{H} 4,83$ & Pick on bottom of sandstone & Heebner_sh & Wells & Vamoosa middle \\
\hline & & Heebner Shale Bed & Base & $\mathrm{H} 5,99$ & Top of thin limestone marker below Heebner shale & Vamoosa_middle & Wells & Reference- \\
\hline & & lower Vamoosa & Top & H6, 93 & $\begin{array}{l}\text { Top highest sandstone or limestone below base } \\
\text { of Heebner shale }\end{array}$ & Vamoosa_lower & Wells & Checkerboard_Ls \\
\hline Pta & Tallant Formation & & Top & & & Tallant_Fm & Map trace & Checkerboard_Ls \\
\hline Pbd & Barnsdall Formation & & Top & $\mathrm{H} 7,65$ & Base of Bigheart sandstone & Barnsdall_Fm & $\begin{array}{l}\text { Map trace, } \\
\text { wells }\end{array}$ & Checkerboard_Ls \\
\hline Pwi & $\begin{array}{l}\text { Wann Formation, } \\
\text { Iola Limestone }\end{array}$ & & Top & & & Wann_Iola_Chanute_Fms & Map trace & Checkerboard_Ls \\
\hline Pch & Chanute Formation & & Top & & & combined with above & Map trace & Checkerboard_Ls \\
\hline Pnh & $\begin{array}{l}\text { Nellie Bly Formation and } \\
\text { Hogshooter Limestone }\end{array}$ & & Top & & & NellieBly_Hogshooter_Fms & Map trace & Checkerboard_Ls \\
\hline \multirow[t]{2}{*}{ Pcc } & Coffeyville Formation & & Top & & & Coffeyville_Fm & Map trace & Checkerboard_Ls \\
\hline & $\begin{array}{l}\text { Checkerboard Limestone } \\
\text { Member }\end{array}$ & & Top & $\mathrm{H} 8,236$ & Top of thin limestone marker interval & Checkerboard_Ls & Wells & Reference \\
\hline
\end{tabular}




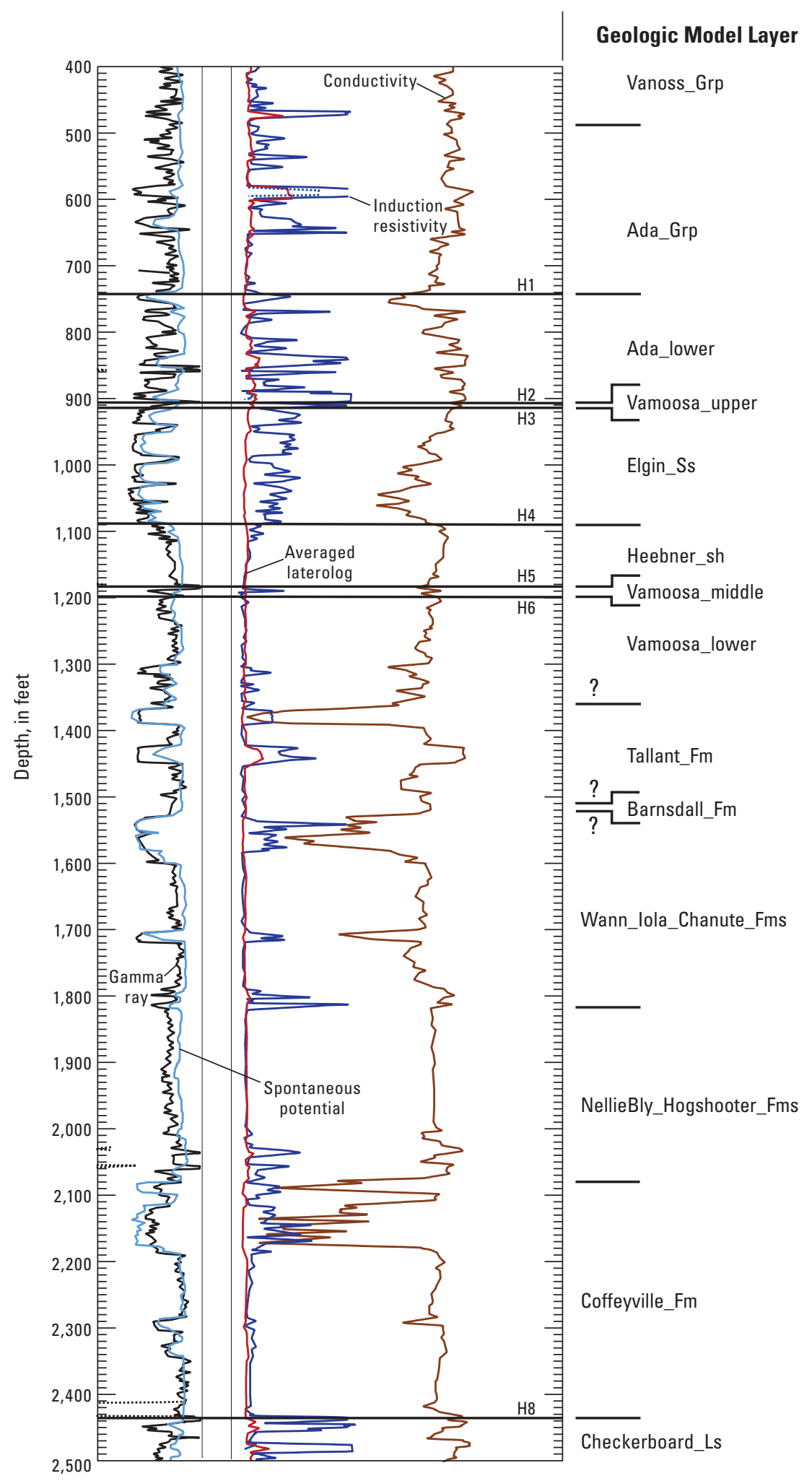

Figure 4. Example of wire-line log from northwestern Osage County (see figure 3) digitized from the Cole cross sections (Boyd, 2011) showing selected horizons ("picks") of stratigraphic units and regional marker beds. Correlations to geologic model layers for Osage County are queried where uncertain. 
Branson (1957), are well correlated throughout Osage County on Cole's M-series cross sections. Well depths to their top give a consistent horizon (H1) for the top of the lower part of the Ada Group whereas well depths to their base give a pick (H2) for the base of the Ada Group and the corresponding top of the Vamoosa Group. Within the upper part of the Vamoosa Group, the Elgin Sandstone Lentil forms a widespread sandstone interval that was deposited in a distributary delta system (Brown, 1967). Well picks to the top of the Elgin (H3) range from 3 to $208 \mathrm{~m}$ below the base of the H2 limestone horizon, with the intervening interval of the upper Vamoosa Group having wire-line log signatures of shale and interbedded sandstone. Picks for the base of the Elgin define the $\mathrm{H} 4$ horizon and give a unit thickness compared to $\mathrm{H} 3$ that ranges from 8 to $89 \mathrm{~m}$. The interval below the Elgin includes a widespread shale horizon at the base, correlative with the Heebner Shale Bed of south-central Kansas (Branson, 1957) and a widespread but thin limestone interval at the base of the shale whose top was the pick for H5. A predominantly shale-rich interval of the middle part of the Vamoosa Group underlies the $\mathrm{H} 5$ horizon and overlies the uppermost sandstone and (or) limestone that was picked for the H6 horizon, a top of a lower Vamoosa Group interval. Beneath the Vamoosa Group, Tallant Formation includes the basal Bigheart Sandstone Member (Tanner, 1956) in the east-central part of the county, whose base forms the $\mathrm{H} 7$ horizon and the corresponding top of underlying Barnsdall Formation. The lowest pick, the H8 horizon, is on the top of the Checkerboard Limestone Member of the Coffeyville Formation which extends in the subsurface beneath the entire county (Cole, 1967). The two laterally extensive horizons with the greatest number of well data (table 1), the base of the Heebner Shale Bed (H5) and the top of the Checkerboard (H8) were designated as reference horizons for building the 3-D geologic model as discussed in the following section.

\section{Geologic Model Construction and Methodology}

EarthVision software (Dynamic Graphics, Inc.) was used to create and display the 3-D geologic model because of the ability of the software to interactively use and view different data types. The software can define geologic surfaces while maintaining structural complexity and integrity in three dimensions. The software creates 3-D mathematically defined surfaces from $\mathrm{X}, \mathrm{Y}$, and $\mathrm{Z}$ data points. For this model, $\mathrm{X}$ and Y coordinates are Universal Transverse Mercator (UTM) Ellipsoid, Geodetic Reference System 1980 (GRS 80), North American Datum 1983 (NAD 83), zone 14 in meters; and Z values are elevation in meters, North American Vertical Datum (NAVD 88). Modeled surfaces were derived using the software's native minimum surface-tension gridding algorithm with minimal smoothing to adhere to the data and to provide a realistic geologic surface. The gridded surfaces were generated in a two-stage process using an initial grid estimate followed by biharmonic iterations: (1) As the initial estimate of gridnode spacing was dependent on the spatial distribution of the scattered data, after an initial estimate was complete, the grid nodes were reevaluated by a biharmonic cubic-spline function through a number of iterations. Then (2) to assure that grid nodes still adhered to the data, data were brought back into the calculations using a feedback algorithm. These modeling steps result in the curvature of the surface being distributed between rather than concentrated at data points, generating a more natural looking geologic model surface. More information on these modeling techniques is available from Dynamic Graphics, Inc., at http://www.dgi.com.

The software follows basic geologic rules to define depositional, channel-fill, or unconformable surfaces. Surfaces can be modified by adding data points to a surface, altering gridding parameters, or using smoothing algorithms in any of the $\mathrm{X}, \mathrm{Y}$, and $\mathrm{Z}$ dimensions. Surfaces were modeled using existing data. If necessary, because of faulting or characteristics of the modeling algorithms, artificial data points may have been added to better define an unconstrained area of a surface. Details of the algorithms and how data points are used by the software are beyond the scope of this report but are available from Dynamic Graphics, Inc., at http://www.dgi.com.

Model construction of Osage County started with data derived from geologic map contacts from Heran and others (2003). Contact surfaces were interpolated and projected into the subsurface based on initial estimates of strike and dip of bedrock layers. All bedrock layers were modeled as depositional type in the software and represented by the top surface of the respective model layers (table 1). Subsurface projections of layer surfaces were refined using information from picks on drill hole wire-line geophysical logs. We used two-dimensional (2-D) and 3-D visual analyses of data sets then reviewed the results. The interpretations and modeling techniques were validated and modified to refine the model in an iterative process.

Geologic bedrock layers in the model (fig. 5; table 1) are laterally extensive, of low dip and relief, and broken by minimal faulting. Because faults in the area are short and generally have less than $15 \mathrm{~m}$ of throw (Bass, 1942), they were too small to be included in the county model. Drill-hole data from wire-line log picks confirm the general west-northwest dip of the bedrock layers but also define smaller model layer surface variations (fig. 5). The lowest Checkerboard Limestone Member surface (H8, Checkerboard_Ls) is constrained by the most drill hole data and thus was designated as a reference surface to guide modeling of other lower layers of the geologic model. Likewise, the middle Vamoosa surface (H5, Vamoosa_middle) also had abundant drill-hole information and was used as a reference surface for overlying horizons in the upper part of the geologic model. 

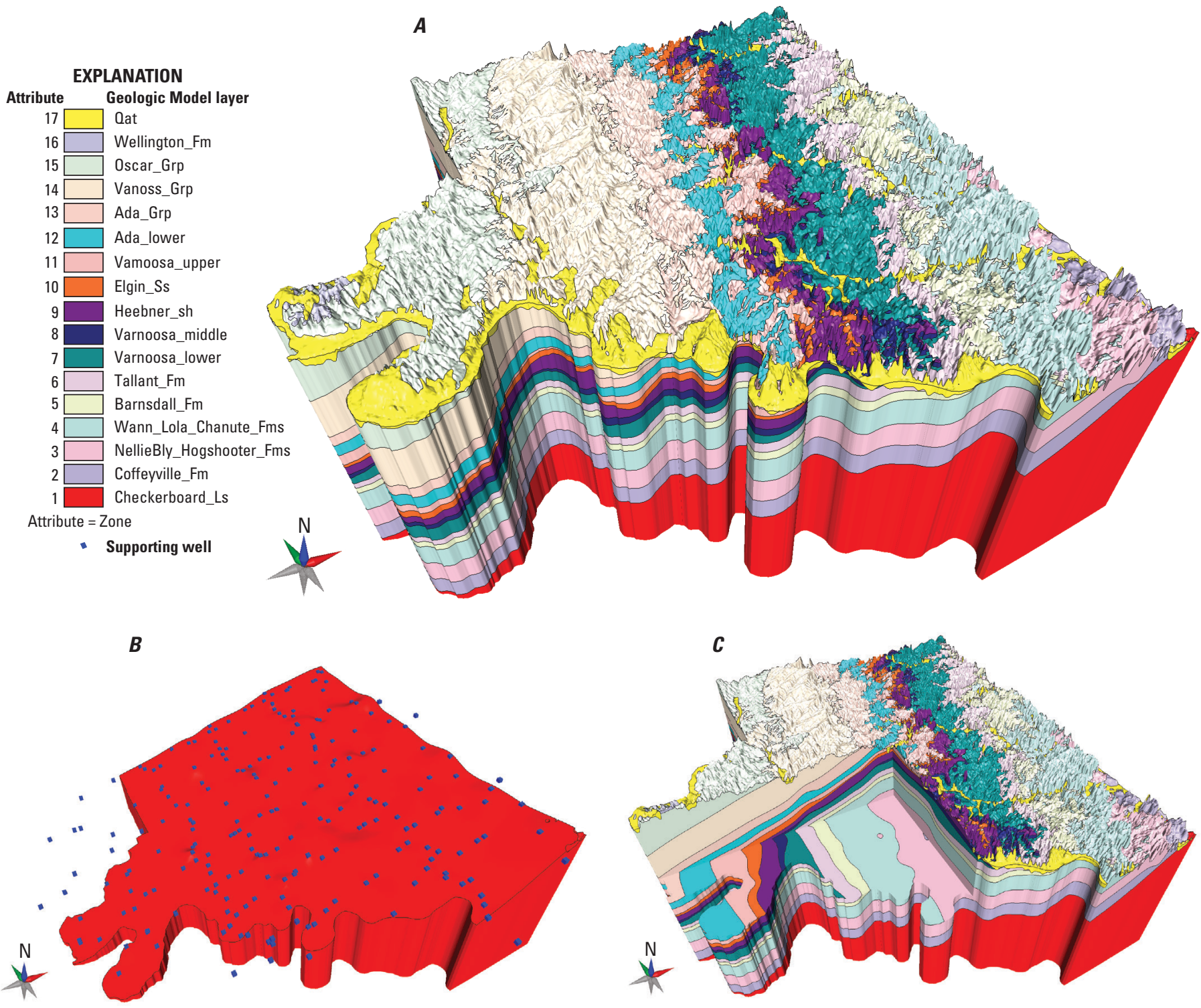

Figure 5. Images of three-dimensional (3-D) geologic model for Osage County, looking to the northeast with $30 \times$ vertical exaggeration. $A$, Perspective view of full model. $B$, Top of Checkerboard_Ls model layer, with distribution of supporting well control data. $C$, Chair cut illustrating down-dip projections of geologic model layers

Quaternary alluvial deposits from Heran and others (2003) were included in the geologic model to fill major drainages, but modeling of these deposits was more complicated due to their small extent, limited data availability, and the nature of the surface gridder of the software. The major drainages in Osage County are long channels that are narrow and shallow relative to the scale of the model. Drill-hole data for the base of alluvial deposits were only available for areas adjacent to the Arkansas River in the southwestern part of Osage County (Mashburn and others, 2003). Elsewhere, artificial data points were added in order to sculpt unconformity surfaces to fill the drainages with alluvial deposits. Drainage sides are steep and to control their depth, elevations of artificial data points were iteratively adjusted until the drainage unconformity was rendered in the model. To limit the depths and to set parameters of the Quaternary model layer, the channels and depths were first developed on an artificial DEM surface whose elevation was $10 \mathrm{~m}$ greater than the topographic surface. Afterwards, the final model was cut by the true DEM to give the topographic surface. Nonetheless, in many areas the depth of the channel is probably deeper than reality, an effect of the software gridder utilizing parameters for the unconformity surfaces that were appropriate for the countywide scale of the model, but not ideal for representation of alluvial fills of small individual drainages. 


\section{Geophysical Data and Modeling}

\section{Airborne Geophysical Survey}

The Osage Nation provided the USGS with SkyTEM electromagnetic geophysical data collected and documented by Exploration Resources International Geophysics, LLC (XRI). The airborne survey data and report were provided to the Osage Nation in March 2014. The XRI survey employed the SkyTEM time-domain electromagnetic (TDEM) system. Electromagnetic (EM) geophysical methods used for mineral and groundwater prospecting exploit the laws of electromagnetic induction, whereby a time-varying magnetic field from a transmitter coil induces eddy currents in the near surface of the Earth. These currents in turn create a time-varying secondary magnetic field - also called the earth response - that is detected by one or more receiver coils. The earth response at every measurement location can then be matched to the theoretical response of a layered earth model, usually through an iterative computer modeling process that adjusts the electrical resistivity value of each of the model layers until a specified closeness of fit to the earth response is reached. The resistivity-depth profile arrived at is then interpreted to agree with likely geologic stratigraphy. Interpretation is complicated by the fact that bulk earth resistivity is a complex function of many variables, the most important of which are the lithology, the hydraulically connected porosity, and the chemistry of the saturating fluid or interstitial water. For example, consider the case of a sand or gravel deposit, in which individual grains have typically very high electrical resistivity. An unsaturated or dry deposit will have higher bulk resistivity than the same deposit saturated with water, and higher still than the same deposit saturated with brackish or saline water. The presence of clays, which have a high ion-exchange capacity, can dramatically lower the resistivity even further (Keller, 1987, 1989).

Despite the challenges of interpreting resistivity values in terms of the geologic media, the helicopter-borne TDEM method has been successfully used in recent years to map the geology of shallow aquifers (Bedrosian and others, 2014; Ball and others, 2015). Technical details of the TDEM method can be found in Nabighian and Macnae (1991), Danielsen and others (2003), and Fitterman and Labson (2005).

The primary reconnaissance survey covered Osage County with east-west flight lines spaced $5 \mathrm{~km}$ apart and north-south tie lines at $10 \mathrm{~km}$ apart, for a total of 1,798 line$\mathrm{km}$ over 5,557 square $\mathrm{km}\left(\mathrm{km}^{2}\right)$ (fig. $\left.6 A\right)$. The north-south tie lines were not used in model interpolations, and are not shown in figure 6 . In this draped survey, with the transmitter/receiver system kept at about $46 \mathrm{~m}$ above topography, flight lines were oriented perpendicular to geologic strike in order to more clearly` delineate geologic contacts and to map resistivity variations as a function of the dip of underlying strata. Based upon an initial assessment of the reconnaissance data, two higher resolution surveys were flown: The first, over a zone of low apparent resistivity centered on Burbank, called the "Burbank Block" (fig. 6), consisting of 532 line-km over $250.6 \mathrm{~km}^{2}$. The second, over a zone of high apparent resistivity called the "North Block," consisting of 184 line-km over $83.16 \mathrm{~km}^{2}$ (fig. $6 A$ ). XRI processed the data to produce 2-D apparent resistivity maps, and inverted the data, using a laterally constrained inversion (LCI) in Aarhus Workbench (Aarhus University, 2015) to produce 2-D resistivity-versus-depth profiles. The LCI approach connects the one-dimensional profiles of adjacent soundings to produce smoother, more continuous depth sections along the flight lines (Auken and others, 2005). Because data density along flight lines is very high (approximately one sample every $50 \mathrm{~m}$ ) compared to the spacing between flight lines $(5,000 \mathrm{~m})$, it was necessary to interpolate synthetic resistivity profiles between the primary flight lines in order to create a high resolution 3-D model space for the entire survey. Therefore, secondary and tertiary resistivity profiles were generated, with the secondary profiles midway between the primary lines, and the tertiary profiles midway between the primary and secondary profiles. The entire set of profiles is shown in figure $6 B$, with primary lines in blue, secondary lines in green, and tertiary lines in orange.

\section{Data Quality Assurance}

A prudent first step in using preprocessed third-party data is to assess data quality through a standard statistical analysis of all data channels, particularly positioning (X-, $\mathrm{Y}$-, and Z-coordinates) and inverted resistivity values. This analysis identified data outliers, such as physically impossible changes in aircraft speed and sample spacing, elevation, variable sample spacing indicating re-flights at different airspeeds, as well as data gaps due to impermissible airspace (for example, over dwellings), or to excessive systematic or cultural noise. This analysis determined that the original Topo channel representing terrain elevation was inaccurate, and was superseded by a new DEM channel, which was created by resampling a USGS 10-m DEM grid file. Important summary statistics for the principal data channels are given in table 2. The number of electromagnetic soundings that passed statistical validation tests are 18,670 for the Burbank Block; 6,565 for the North Block; and over 22,880 for the reconnaissance survey.

Only the reconnaissance survey data are considered in this report, in keeping with the regional scale of the EarthVision geologic model. Further analysis of the resistivity framework would be possible in the Burbank and North Block areas if more detailed investigations were desired in these areas. 
$\boldsymbol{A}$ Osage Nation, survey flight lines

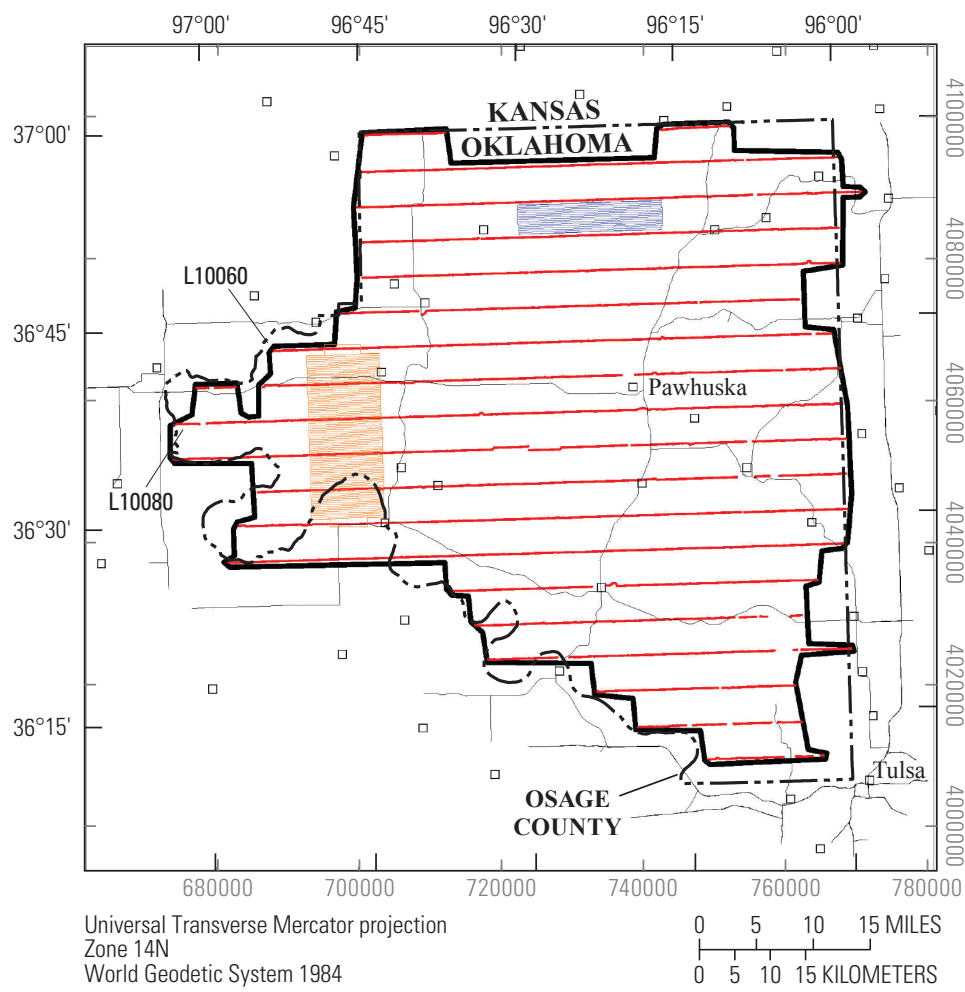

\author{
EXPLANATION \\ Flight lines \\ Reconnaissance \\ _ North Block \\ _ Burbank Block \\ — Survey boundary
}

B

Osage Nation, EarthVision geologic layers
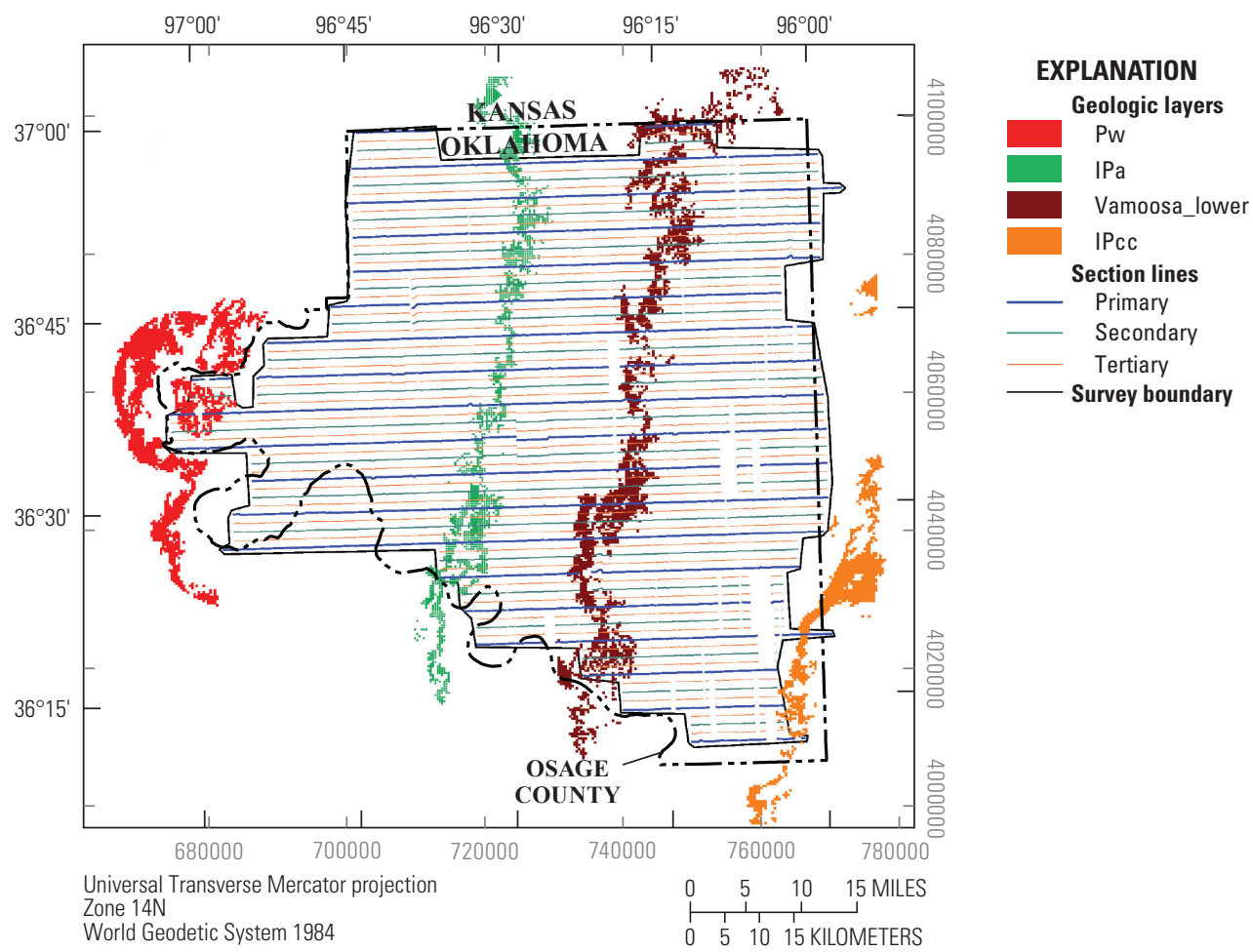

Figure 6. A, Index map showing airborne electromagnetic survey flight lines in which east-west flight lines for the reconnaissance, Burbank and North Blocks are drawn in red, orange, and blue, respectively. Thin black lines are highways and open squares are towns. $B$, Primary (blue), secondary (green), and tertiary (orange) section lines overlie topographic surface projections of the Wellington_Fm, Ada_Grp, Vamoosa_lower, and Coffeyville_Fm geologic model layers, in red, green, brown, and orange pixels. Numbers preceded by “L” are flight lines. The north-south tie lines were not used in model interpolations, and are not shown. 


\section{Development of Electrical Resistivity Cross Sections}

XRI inverted each sounding to produce a model of earth resistivity as a function of depth below ground surface using laterally constrained and spatially constrained inversion algorithms. The inversions were based on a 19-layer earth model, with layers 1 through 18 extending to $300 \mathrm{~m}$ below theoretical ground surface and the 19th layer as an infinite half-space basement. The layers increase in thickness with depth, ranging from $5.0 \mathrm{~m}$ for the top layer to $38.2 \mathrm{~m}$ for the bottom layer (table 3). Inverted resistivity values are posted at the middle points of each layer, resulting in an 18-point resistivity profile at each X-Y measurement point along the flightlines. The creation of resistivity depth-sections by gridding of the original 18 resistivity values yielded a blocky representation of earth resistivity. To improve the graphical display of resistivity variations versus depth in two- and three-dimensional views, a 35 -point resistivity profile was created for each vertical profile by interpolating 17 values between the original 18 points using a spline-curve fitting function, which resulted in a much smoother representation of the resistivity cross-sections. To improve the aspect ratio of the cross-section plots, a vertical exaggeration of 20 was applied. Gridding was carried out using a cell size of $60 \mathrm{~m}$, which preserved the along-line data density as well as the 35 resistivity data points with depth.

For each sounding, the inversion software computes a parameter called the depth of investigation (DOI) to give upper and lower bounds on the depth to which useful resistivity values can be estimated. The DOI can be deep over highly resistive geology, or shallow over low-resistive geology. In situations where the Earth is composed of layers of contrasting resistivity values, the DOI falls between the shallowest and deepest attainable in the survey area. Of the two bounds, this research used the lower bound (DOI_LOWER channel) as a cutoff for the resistivity profiles, as it retains more inverted data. Resistivity values for layer depths below the DOI_LOWER limit were discarded, which gives the resulting resistivity sections an irregular thickness in the vertical dimension (elevation). An example of a final gridded resistivity section is shown in figure $7 A$, in which geologic layers are clearly discernible due to contrasting earth resistivity properties. The rainbow color scale ranges from red to blue, denoting resistivities from high to low, respectively. All of the sections displayed in a curtain fence diagram give a representation of layered earth resistivity over the entire survey area (fig. $7 B$ ).

Two-dimensional maps of apparent resistivity at fixed depths below ground surface are obtained by gridding the $\mathrm{X}, \mathrm{Y}$, and resistivity data channels without reference to terrain elevation. For example, the depth of the R07 resistivity channel corresponds to the middle depth of Layer 7 between the top and bottom depths given in table 3, which amounts to $46.55 \mathrm{~m}$. Thus, 2-D gridding of the R11 channel, which has a depth of $-99.30 \mathrm{~m}$ from the middle of Layer 11, gives the result shown in figure $8 \mathrm{~A}$. This procedure can be followed for all the R-data channels. However, blank areas start to show up in the maps for the deeper model layers as the depth exceeds the DOI and fewer valid values are available for gridding.

Table 2. Summary statistics for principal data channels.

[Std. dev., standard deviation; N/A, not available]

\begin{tabular}{|c|c|c|c|c|c|}
\hline Channel & Units & Maximum & Minimum & Mean & Std. dev. \\
\hline $\mathrm{X}$ & UTM meters & 770557.3 & 673972.9 & 729899.3 & N/A \\
\hline TOPO & meters & 406.9 & 180.7 & 284.6 & 40.2 \\
\hline DOI_L̄OWER & meters & 229. & 13.7 & 129.8 & 33.5 \\
\hline $\mathrm{R} 01$ & ohm-meters & 241.34 & 2.05 & 23.13 & 15.64 \\
\hline $\mathrm{R} 02$ & ohm-meters & 209.51 & 5.01 & 27. & 15.88 \\
\hline R05 & ohm-meters & 171.82 & 1.38 & 21.21 & 15.63 \\
\hline R06 & ohm-meters & 152.41 & 1.67 & 19.81 & 14.62 \\
\hline R07 & ohm-meters & 122.97 & 1.92 & 17.87 & 13.21 \\
\hline R08 & ohm-meters & 113.59 & 1.18 & 15.88 & 11.1 \\
\hline R09 & ohm-meters & 81.39 & 1.22 & 14.27 & 9.42 \\
\hline $\mathrm{R} 10$ & ohm-meters & 77.56 & 1.38 & 12.89 & 8.63 \\
\hline $\mathrm{R} 15$ & ohm-meters & 41.92 & 1.59 & 7.63 & 4.33 \\
\hline $\mathrm{R} 16$ & ohm-meters & 35.42 & 1.28 & 7.49 & 3.76 \\
\hline $\mathrm{R} 17$ & ohm-meters & 30.67 & 2.35 & 7.49 & 3.26 \\
\hline $\mathrm{R} 18$ & ohm-meters & 27.92 & 2.83 & 7.5 & 2.91 \\
\hline
\end{tabular}


Table 3. Layered-earth model parameters for resistivity inversions. [m, meter]

\begin{tabular}{cccc}
\hline Layer & Top $(\mathbf{m})$ & Bottom $(\mathbf{m})$ & Thickness $(\mathbf{m})$ \\
\hline 1 & 0 & -5 & 5 \\
2 & -5 & -10.6 & 5.6 \\
3 & -10.6 & -17 & 6.4 \\
4 & -17 & -24.2 & 7.2 \\
5 & -24.2 & -32.3 & 8.1 \\
6 & -32.3 & -41.4 & 9.1 \\
7 & -41.4 & -51.7 & 10.3 \\
8 & -51.7 & -63.3 & 11.6 \\
9 & -63.3 & -76.3 & 13 \\
10 & -76.3 & -91 & 14.7 \\
11 & -91 & -107.6 & 16.6 \\
12 & -107.6 & -126.3 & 18.7 \\
13 & -126.3 & -147.3 & 21 \\
14 & -147.3 & -171 & 23.7 \\
15 & -171 & -197.7 & 26.7 \\
16 & -197.7 & -227.8 & 30.1 \\
17 & -227.8 & -261.8 & 34 \\
18 & -261.8 & -300 & 38.2 \\
\hline
\end{tabular}

Two-dimensional maps of apparent resistivity at constant elevations are obtained by gridding the $\mathrm{X}, \mathrm{Y}$, and resistivity data channels after the model layer depths are subtracted from terrain elevation, yielding sample elevations. Because the sample elevations are as irregularly distributed across the survey area as the terrain elevations, a fixed elevation must be specified and then intermediate R-values corresponding to that elevation are interpolated. For example, R19 on a hill could correspond to R03 in a valley. Gridding the interpolated $\mathrm{R}$ values as a 2-D map gives the result shown in figure $8 A$ and $8 B$. This procedure can be followed for all the interpolated R-data channels. Blank areas start to show up in the maps in high terrains for the deeper model layers when elevation dips below the DOI and fewer valid values are available for gridding.

\section{Construction of 3-D Voxel Model}

Realistic 3-D representations of the distribution of earth resistivity are difficult due to disparate sampling in the X-, $\mathrm{Y}$-, and Z-dimensions. Whereas the interpolated resistivity values in each sounding vary from $2.5 \mathrm{~m}$ at the top of the profile to $80 \mathrm{~m}$ apart at the bottom, each individual sounding is spaced about $50 \mathrm{~m}$ apart along parallel flight lines, which are themselves thousands of meters apart. Preserving the closely spaced resistivity-depth values while bridging the enormous gap between flight lines is problematic, and gridding the entire primary survey dataset using a uniform, small (for example, $10-\mathrm{m})$ cell size is impractical because of the computing requirements (over 5 billion cells). Furthermore, an isometric 3 -D image would depict a thin veneer (roughly 160 -m thick) of resistivities draped over the county's terrain (comprising an area roughly 96,000 by $89,000 \mathrm{~m}$ ). A tradeoff must be made between resolution and coverage when choosing gridding parameters.

The fairly uniform layered geology across the survey area favored the creation of synthetic resistivity cross-sections between the 5-km spaced primary flight lines. Rather than interpolate intervening values using a strictly Cartesian method, such as inverse-distance-squared or minimum curvature, synthetic flight lines were generated by determining the midpoint on the perpendicular between nearest neighbors on adjacent lines. Gaps in either of the two adjacent data lines were honored. A synthetic profile, consisting of resistivity values for the model layer depths in the DOI, was created for this midpoint by linear interpolation between neighboring resistivity values having the same elevation. Elevation differences due to the dips of geologic strata are corrected by vertically aligning the resistivity profiles with reference to EarthVision model layer elevations. Using this method, resistivity values were interpolated in the same geologic horizons. Values that were either above the DEM or below the DOI were assigned dummy values for later removal. Synthetic cross-sections thusly generated are designated as either secondary (interpolated midway between primary flight lines) or tertiary (interpolated midway between primary and secondary cross-sections). The secondary cross-sections more closely honor the original data than the tertiary cross-sections. The resulting coverage is shown in figure $6 B$.

Three-dimensional models were created using the primary and synthetic flight lines, an example of which is given in figure $9 A$. Such models can be sliced along vertical planes (fig. 9B) or horizontal planes (fig. 9C) to reveal the 3-D distribution of earth resistivity in the survey area.

The EarthVision geologic model (fig. 5) encompasses Osage County and consists of 17 model layers (table 1). The airborne electromagnetic survey covered the central portion of the county, and as a result covered much of the modeled geology. Three of the 17 model layers (Qat, Wellington_Fm, and Checkerboard_Ls) have no or negligible exposure in the survey area. In general, the layered electrical resistivity structure correlates well to modeled geologic layers. Dislocations in the registration of resistivity horizons to modeled horizons may be due to inaccurate model layer elevations, lumped (aggregated) geologic layers (the Vanoss_Grp model layer shows evidence of a contiguous highly resistive zone overlying a low resistive zone), or gradual (rather than sharp) gradation of electrical resistivity at layer boundaries. Furthermore, thin model layers, such as Vamoosa_upper and Heebner_sh do not show a distinct resistivity signature. The layers are most pronounced where a high resistivity layer overlies a low resistivity layer. Layer tops of geologic layers in the EarthVision structural model can be seen plotted over the resistivity section from a single flight line in figure $10 \mathrm{~A}$. 
METERS

L10080

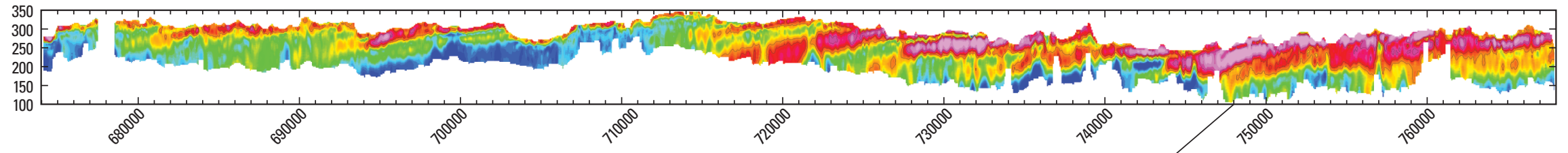

B

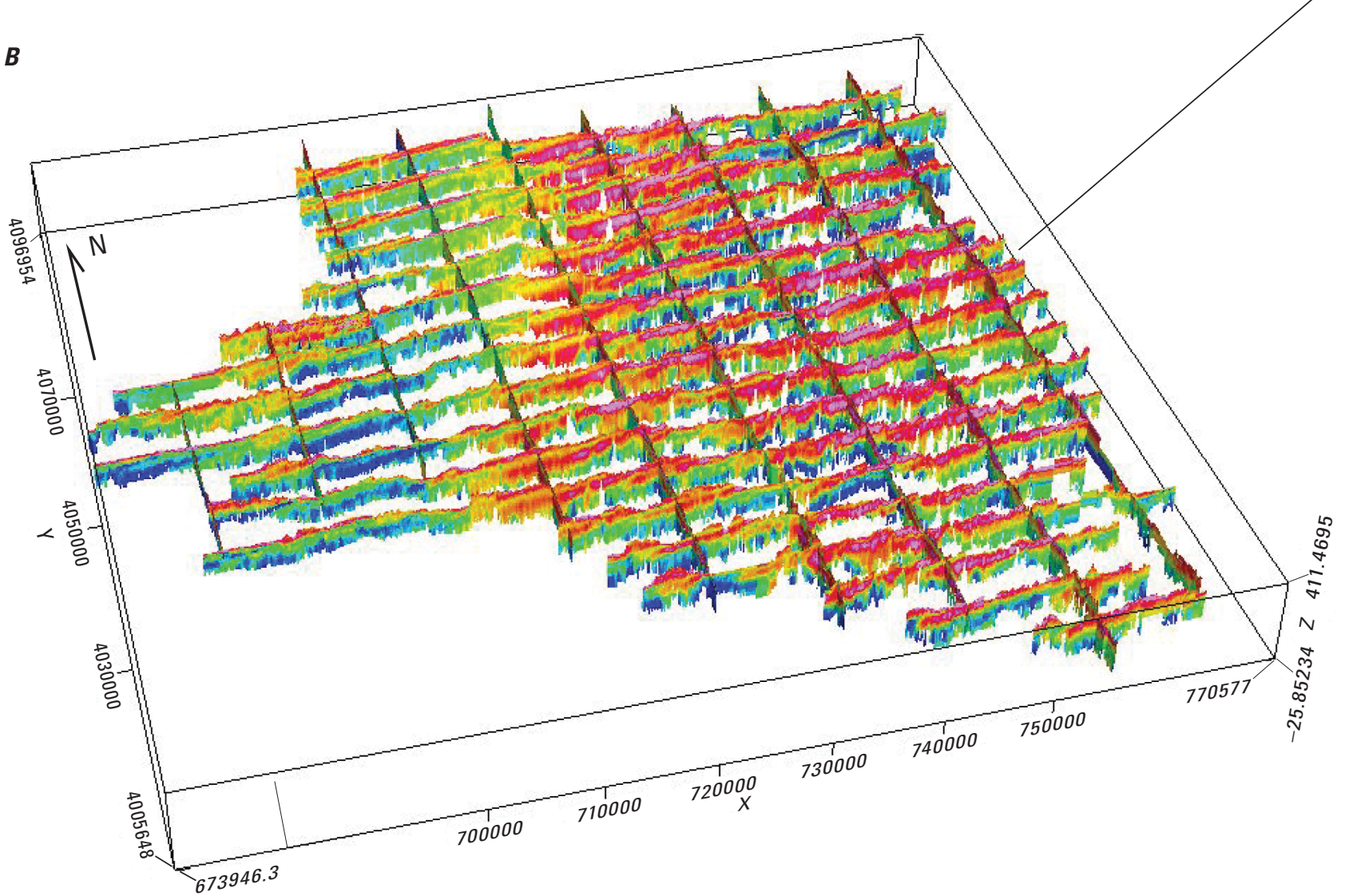

EXPLANATION

Resistivity in ohm-meter

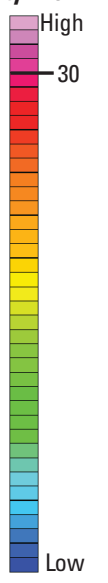

Figure 7. A, Curtain fence diagram of a gridded resistivity cross-section for flight line L10080, revealing layered geology. B, Stacked fence diagram of all reconnaissance survey flight lines. 
A Osage Nation Project, Reconnaissance Survey, Constant Depth BGS Slice

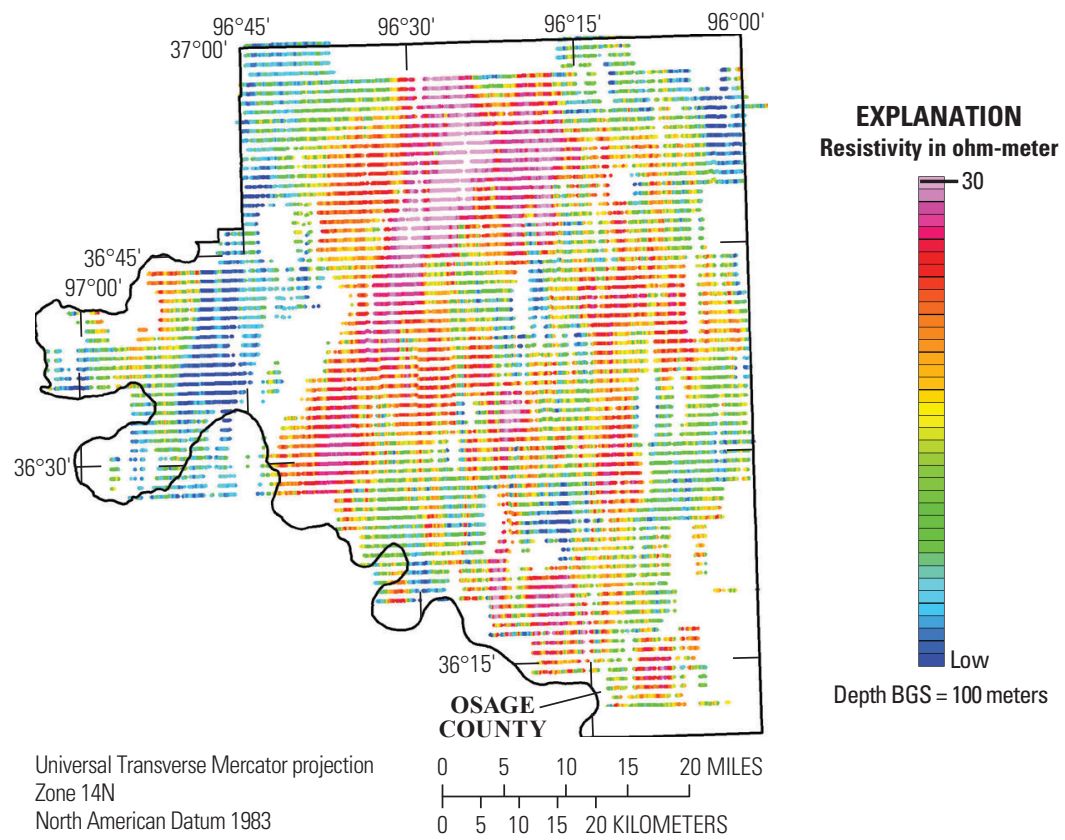

B Osage Nation Project, Reconnaissance Survey, Constant Elevation Slice

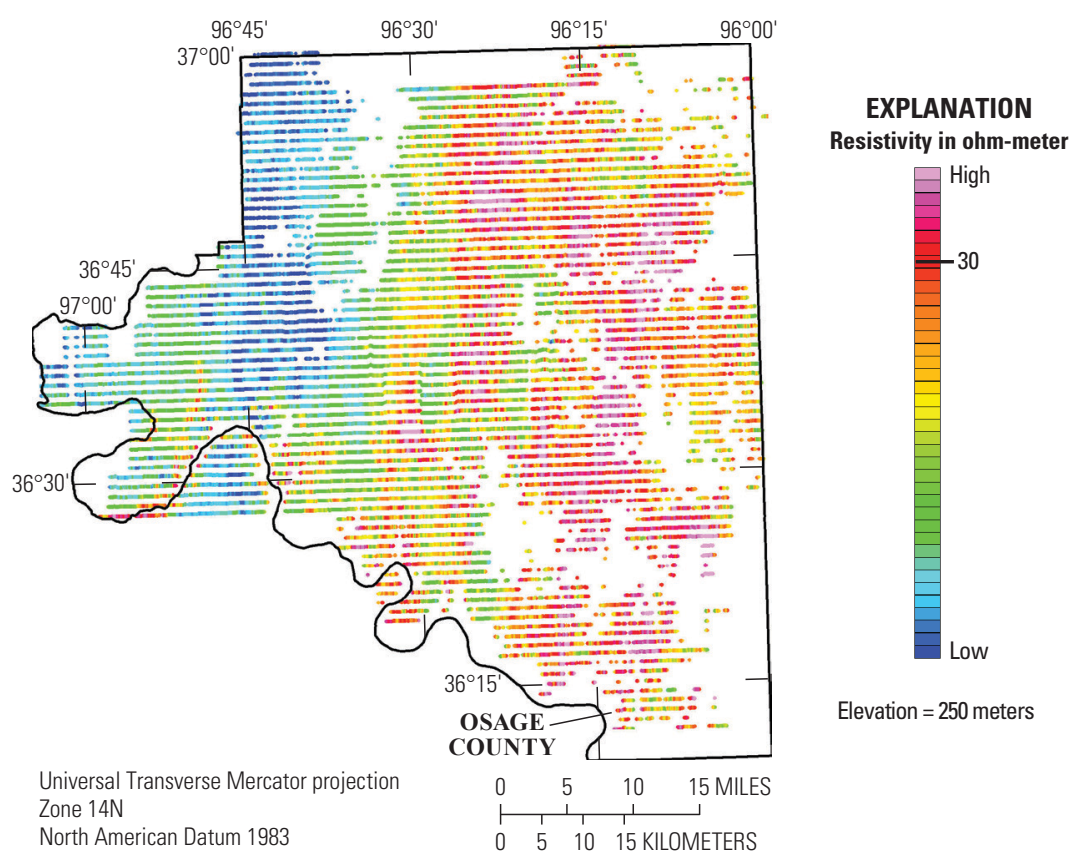

Figure 8. A, Map of inverted resistivity at a depth of $100 \mathrm{~m}$ below ground surface. $B$, Map of inverted resistivity at an elevation of $250 \mathrm{~m}$. Blank areas occur where the fixed elevation dips below the depth of investigation. 


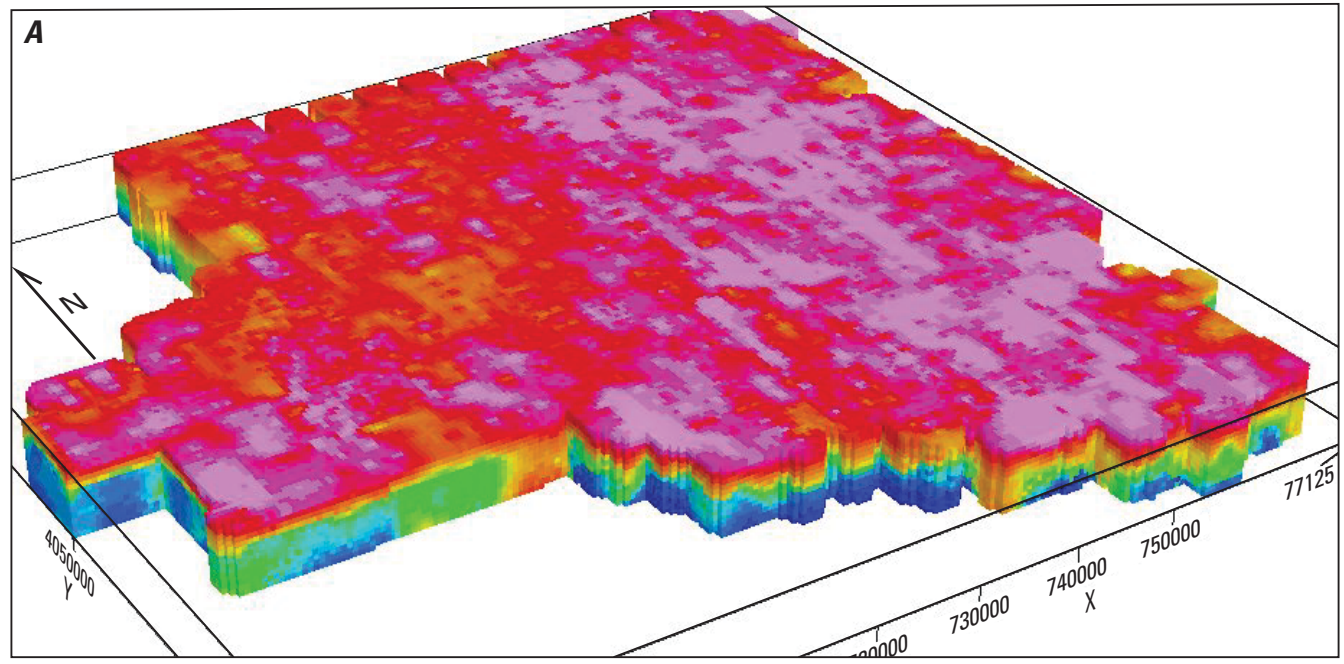

EXPLANATION

Resistivity in ohm-meter
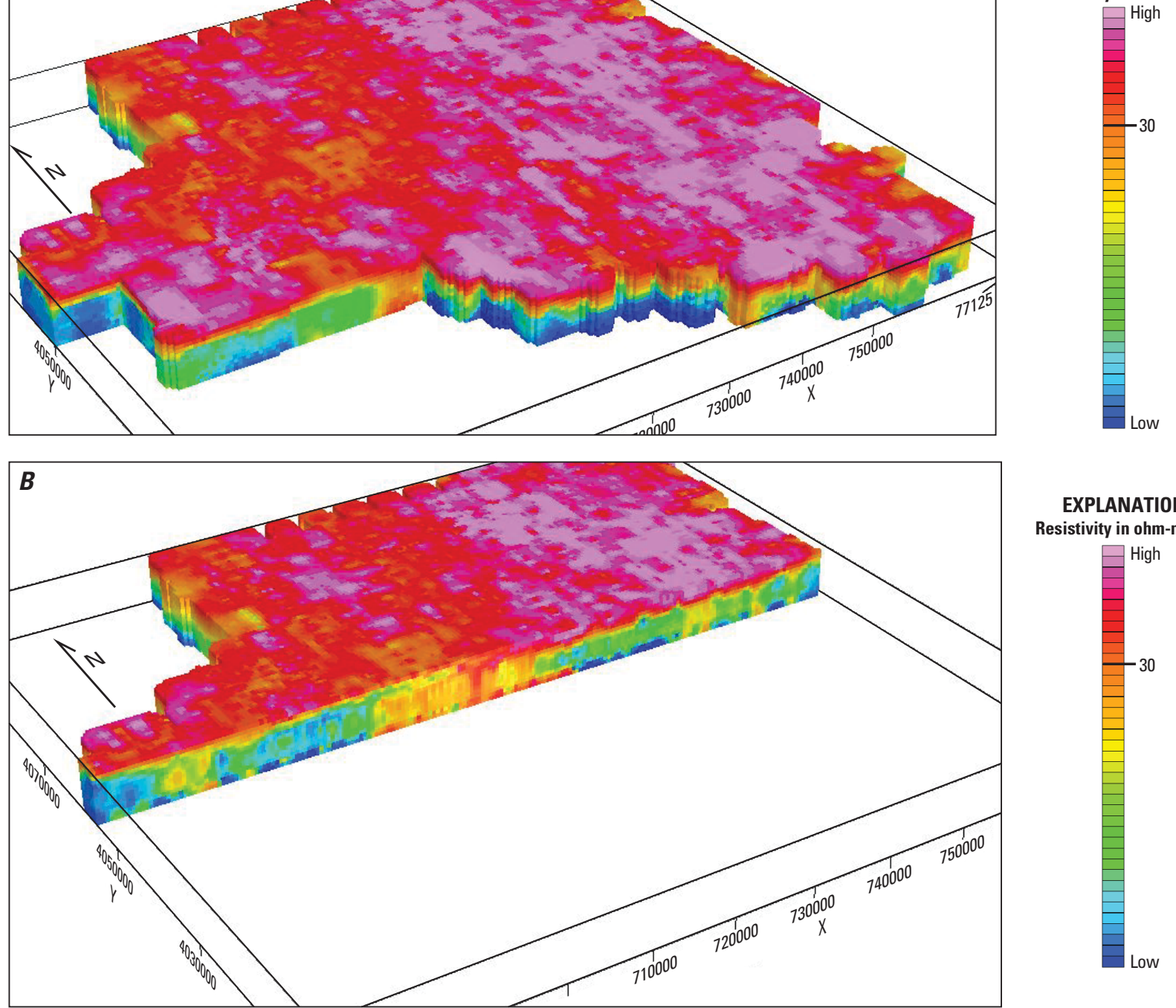

EXPLANATION

Resistivity in ohm-meter

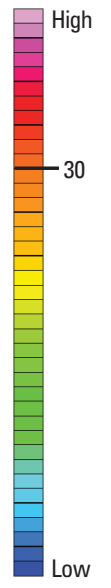

$\boldsymbol{C}$

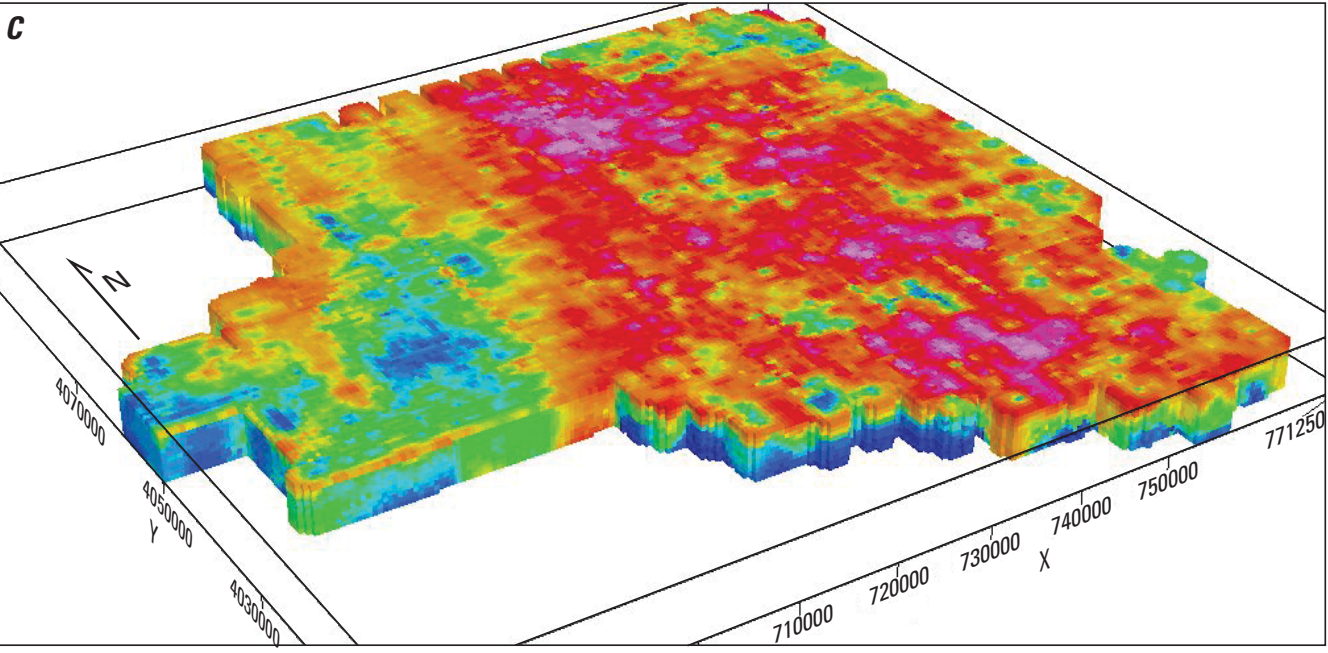

EXPLANATION Resistivity in ohm-meter

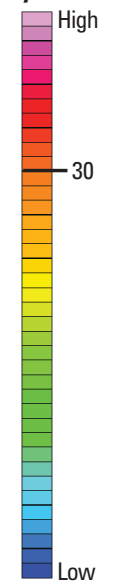

Figure 9. A, Three-dimensional model created from the primary and synthetic secondary and tertiary flight lines. $B$, Vertical slice along a constant $Y$ value. $C$, Horizontal slice along a constant $Z$ (elevation) value. 


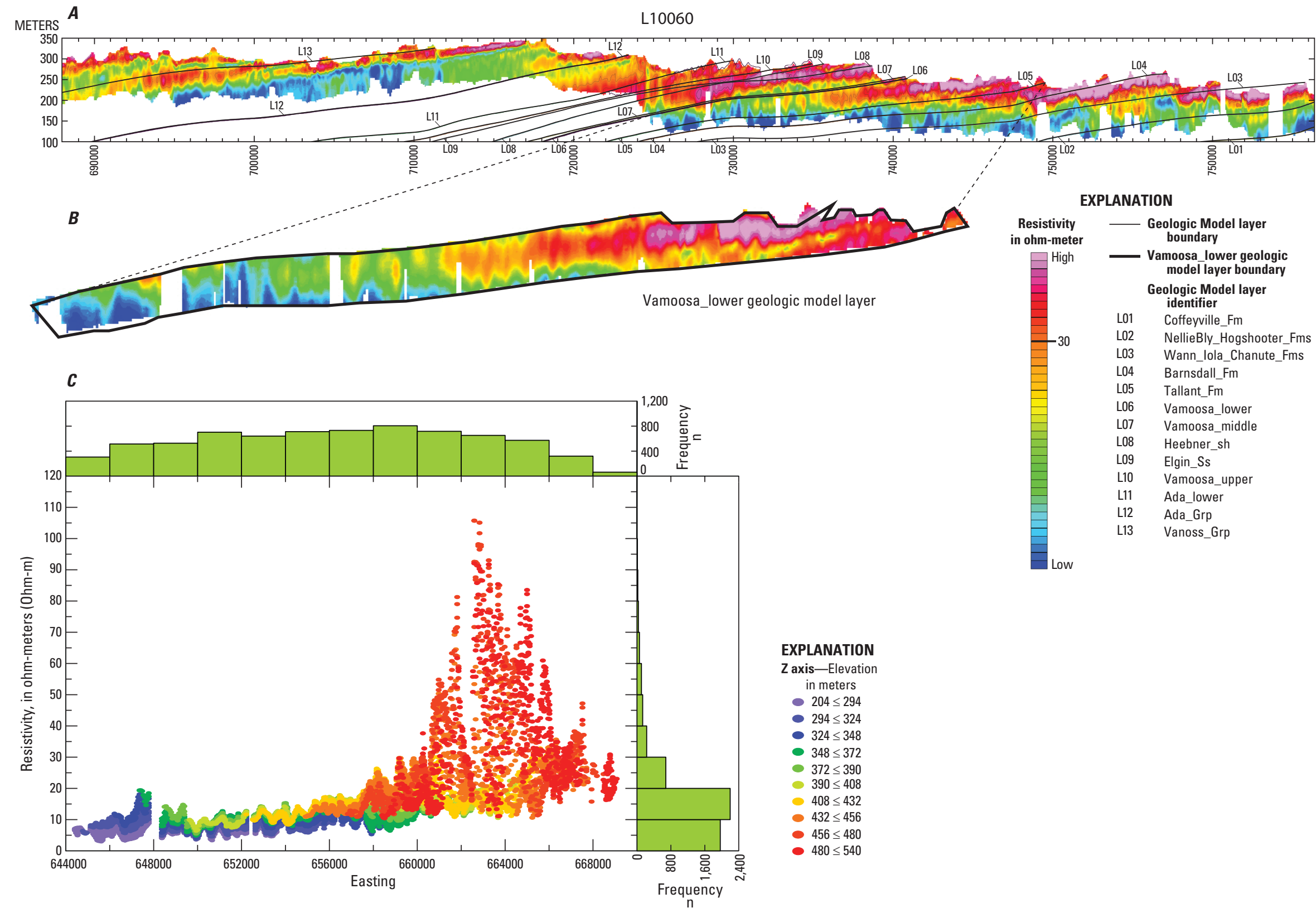

Figure 10. A, Earth resistivity section along flight-line L10060 with geologic model layers superimposed. $B$, Extract of the Vamoosa_lower geologic model layer resistivity section.

$C$, Frequency histograms (green bars) of resistivity data within geologic model layer binned versus resistivity (right) and Easting (top). 
The layer tops from the EarthVision structural model were used to mask resistivity cross-sections, generating isolated datasets of resistivity values for each modeled geologic layer in each survey line. An example from the reconnaissance survey line L10060 (fig. 6) for the Vamoosa_lower layer is shown in figure 10B. The Vamoosa_lower layer was chosen as an example because it is thick and extensive, and is traversed by all but three of the primary flight lines (fig. $6 B$ ). To develop meaningful descriptive statistics for the data corresponding to a given layer, measures were made of the following parameters for each vertical profile in the cross-section. The vertical profile is unique for each $\mathrm{X}$-coordinate in the crosssection. Parameters included: average resistivity, layer thickness, median Z-value (elevation), and depth in layer (meters from top of layer). A histogram of this descriptive statistic is shown in figure $10 C$.

\section{Integrated Geological and Geophysical Model}

To facilitate direct comparisons between electrical resistivity and geology, the AEM data were imbedded in the geologic layers as resistivity-property values using the EarthVision software (fig. 11). This integrated model combines both the full geologic model derived from surface and drill-hole information and the full resistivity-property model derived from the primary flight lines and the interpolated secondary and tertiary profiles. The resistivity-property model was incremented at 5-ohm-m intervals over a range of 0 to $155 \mathrm{ohm}-\mathrm{m}$. The geologic/resistivity-property model was restricted to the depth of useable data above the DOI, generally less than $300 \mathrm{~m}$. This was done by developing an artificial surface for the $\mathrm{Z}$ values of the lower most useable resistivity data, then cropping the model several meters below this surface to ensure all useable data were retained. The topmost geologic/ resistivity-property model surface was cropped by using the DEM plus several additional meters of elevation to again ensure all useable data were obtained without the resistivity property interpolation filling the volumetric space above the ground DEM surface.

By integrating the electrical resistivity model directly as a property in the geologic model, queries can be carried out on the model to display and analyze geologic layers, resistivity units, or combined geologic-resistivity units and ranges (fig. 11).

\section{Discussion}

Modeling of both geologic layers and electrical resistivity from the AEM survey permits a comparison of the two data sets. For bedrock areas, the strong coincidence of west-sloping resistivity gradients with the gentle west dip of geologic strata supports a strong linkage between the two data sets (figs. 10 and 11).

\section{Correlations Between Geology and AEM Results}

\section{Resistivity Volumes}

Integration of the electrical resistivity data as a property in the 3-D geologic model allows calculation of volumes of rock of a defined resistivity range in individual geologic model layers (fig. 12A), using the volumetrics analysis of the EarthVision software. In addition to a full-volume calculation for each model layer within AEM depth-of-investigation, volume estimates were made for six resistivity increments: $0-10,10-20,20-30,30-40,40-50$, and 50-155 (ohm-m). By normalizing for the full volume of each geologic layer, the relative proportion of each resistivity increment is demonstrated (fig. 12B). Because saline waters have low resistivity and freshwater aquifers in sandstone or limestone have high resistivity (Dobrin, 1976), those layers with high proportions of high resistivity are a proxy for potential freshwater aquifers. Although a quantitative relationship between resistivity and water quality has not yet been developed for the aquifers in Osage County, manipulation of resistivity ranges in the integrated geologic/resistivity-property model indicates that volumes with resistivity greater than $30 \mathrm{ohm}-\mathrm{m}$ tend to separate into discrete bodies that align with model layer boundaries. For this report resistivities greater than $30 \mathrm{ohm}-\mathrm{m}$ are designated as "high." For example, the Quaternary alluvial aquifer (Qat model layer) contains relatively high volume with resistivity greater than $30 \mathrm{ohm}-\mathrm{m}$ (fig. 12C). Within the geologic subdivisions of the Vamoosa-Ada aquifer, the Elgin Sandstone Lentil in the upper part of the Vamoosa Group has the highest volume fraction with greater than $30 \mathrm{ohm}-\mathrm{m}$, suggesting that the sandstone is an aquifer subunit in parts of the county (fig. 11C). Below the Vamoosa Group, high proportions of high resistivity are also found in the Tallant, Barnsdall, and combined Wann-Iola-Chanute Formations. In contrast, geologic layers such as the Vanoss and Oscar Groups in the western part of the county, and Coffeyville and Nellie Bly Formations-Hogshooter Limestone in the eastern part of the county, have large percentages of their volume in the lowest resistivity $0-10 \mathrm{ohm}-\mathrm{m}$ increment (fig. 12B, C), and thus are less likely to contain significant amounts of fresh water.

\section{Spatial Variations}

Whereas volume estimates give insight into the overall resistivity distribution for the geologic model layers, images of the integrated 3-D model highlight spatial variations of resistivity in the county and in individual geologic layers. Highresistivity bodies were divided into six classes (A-F) based on their coincidence with different geologic units and are described here (fig. 13A, B). 
A

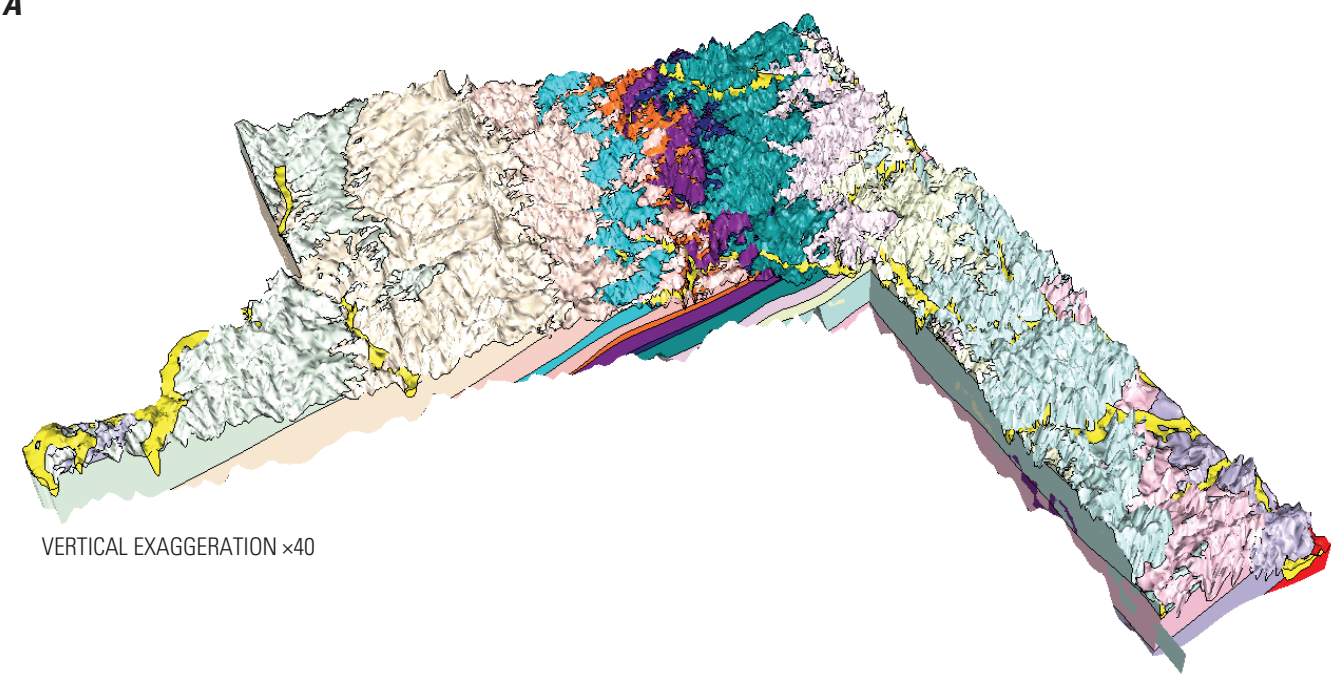

B

C Elgin_Ss layer

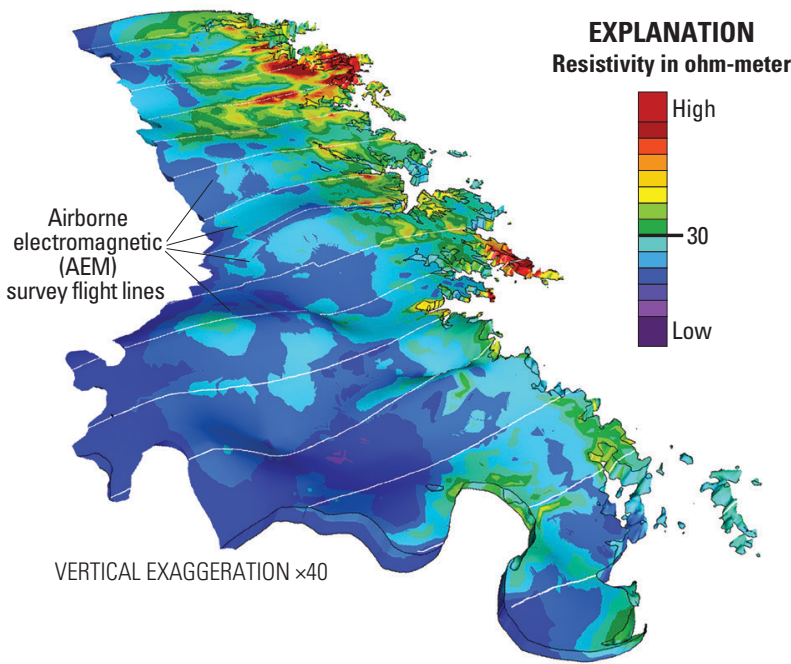

VERTICAL EXAGGERATION $\times 40$

\section{EXPLANATION}

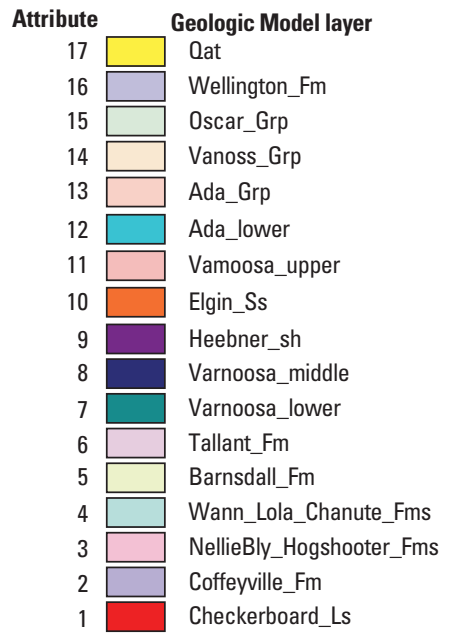

Attribute $=$ Zone

EXPLANATION

Resistivity, in ohm-meter

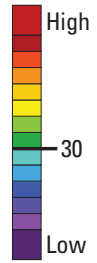

D Tallant_Fm layer

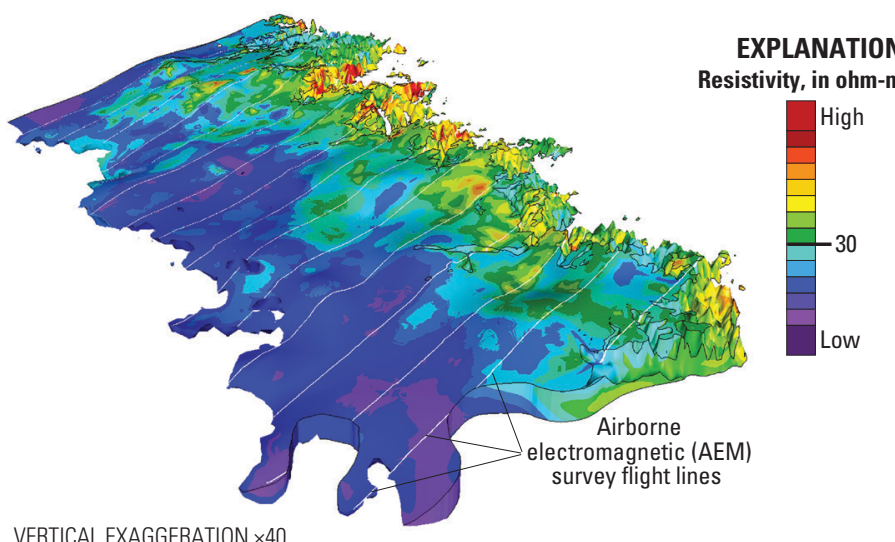

VERTICAL EXAGGERATION $\times 40$

Figure 11. Image of integrated geology-electrical resistivity model, all views looking downward to northeast with a 40X vertical exaggeration. $A$, Geologic layers cut to show westward dip and truncated at the limit of usable resistivity data. $B$, Same view as $A$ but displaying electrical resistivity variations embedded as model property. $C$, View of Elgin_Ss model layer from surface to depth of investigation showing electrical resistivity variations. White lines are drapes of AEM flight lines on layer surface. $D$, Same as $C$ for Tallant_Fm model layer. 


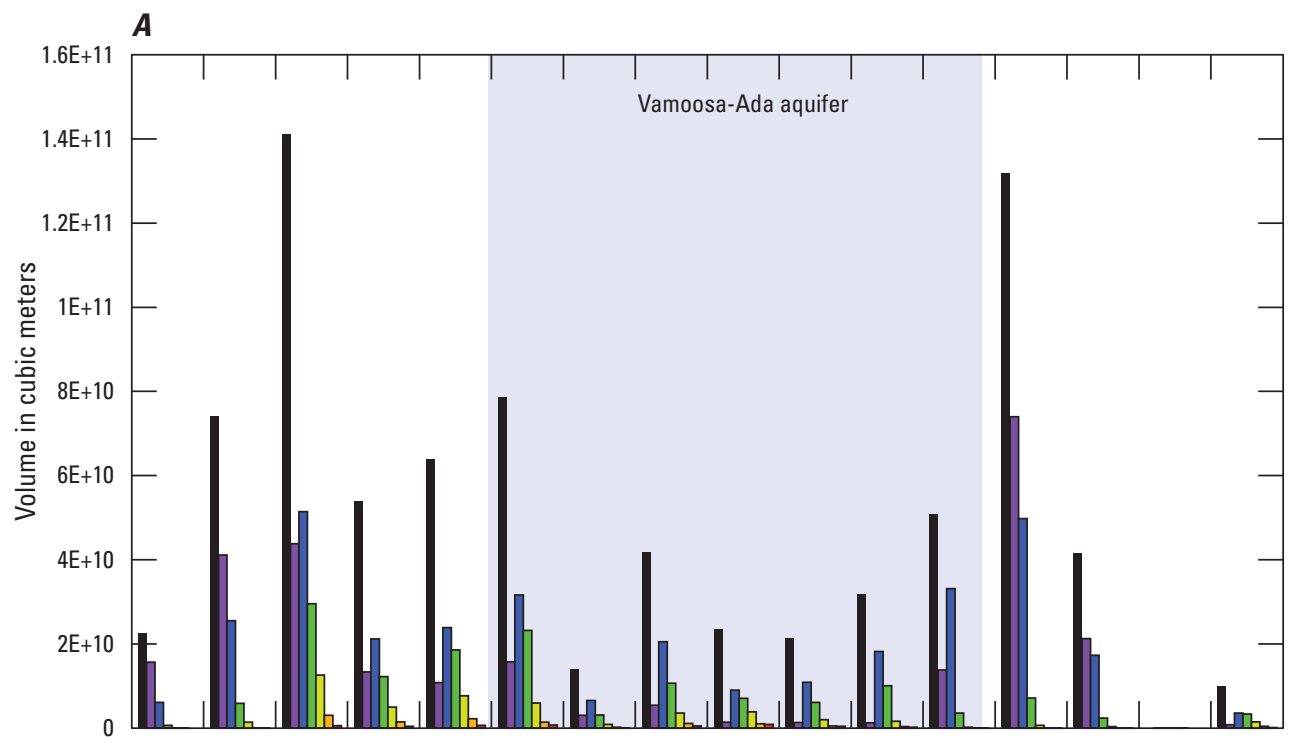

\section{EXPLANATION}

Resistivity, in ohm-meter 0 to 155 0 to 10 10 to 20 20 to 30 30 to 40 40 to 50 50 to 155

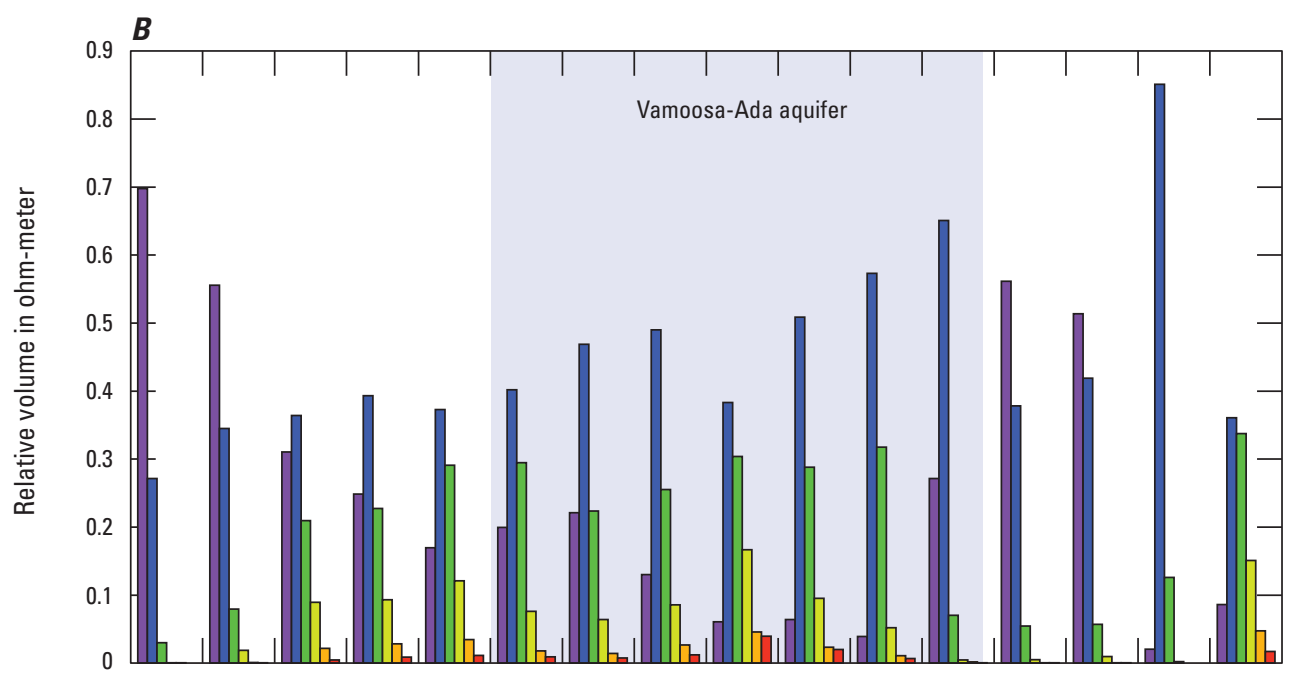

EXPLANATION

Resistivity, in ohm-meter 0 to 10 10 to 20 20 to 30 \30 to 40 40 to 50 50 to 155

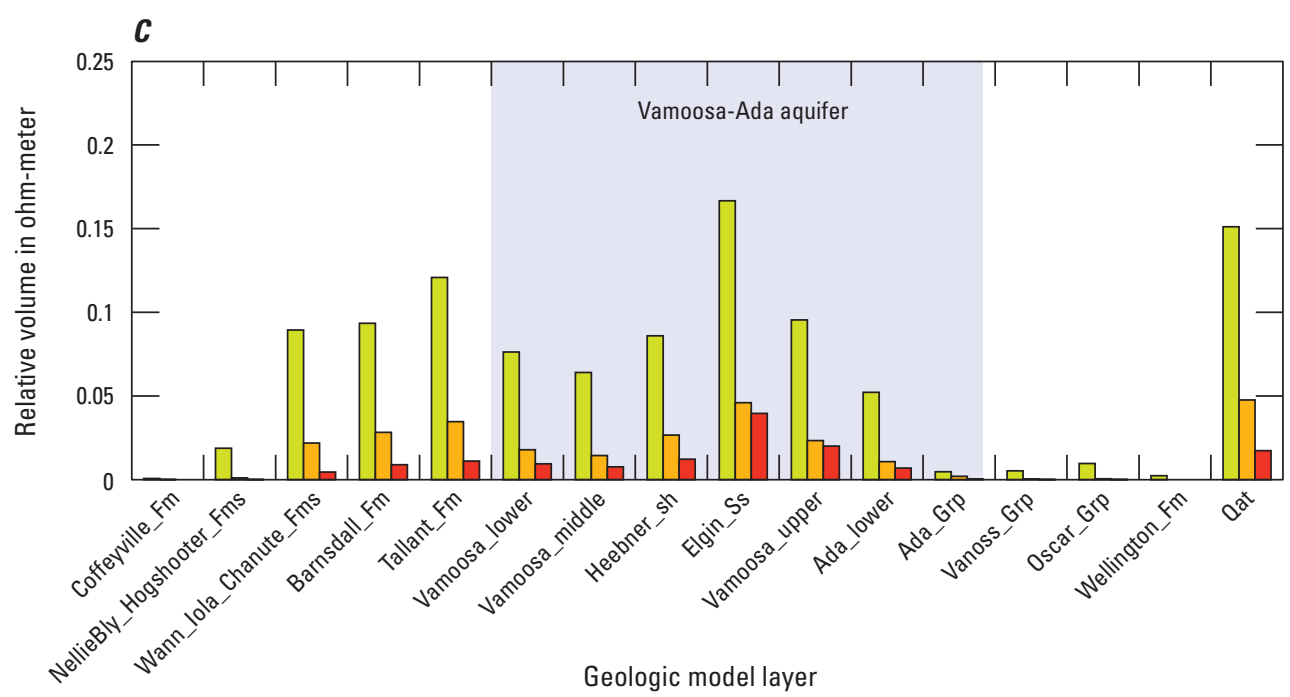

EXPLANATION

Resistivity, in ohm-meter

\30 to 40

40 to 50

50 to 155

Figure 12. Resistivity volumes for geologic layers within the integrated geology-electrical resistivity model. $A$, Volumes of individual geologic model layers for the full resistivity range as well as for $10 \mathrm{ohm}-\mathrm{m}$ increments up to $50 \mathrm{ohm}-\mathrm{m}$ and the remaining higher resistivity values. $B$, Proportion of volume for resistivity increments relative to the full resistivity volume for geologic model layers. $C$, Proportion of volume for resistivity increments greater than $30 \mathrm{ohm}-\mathrm{m}$ relative to the full resistivity volume for geologic model layers. 

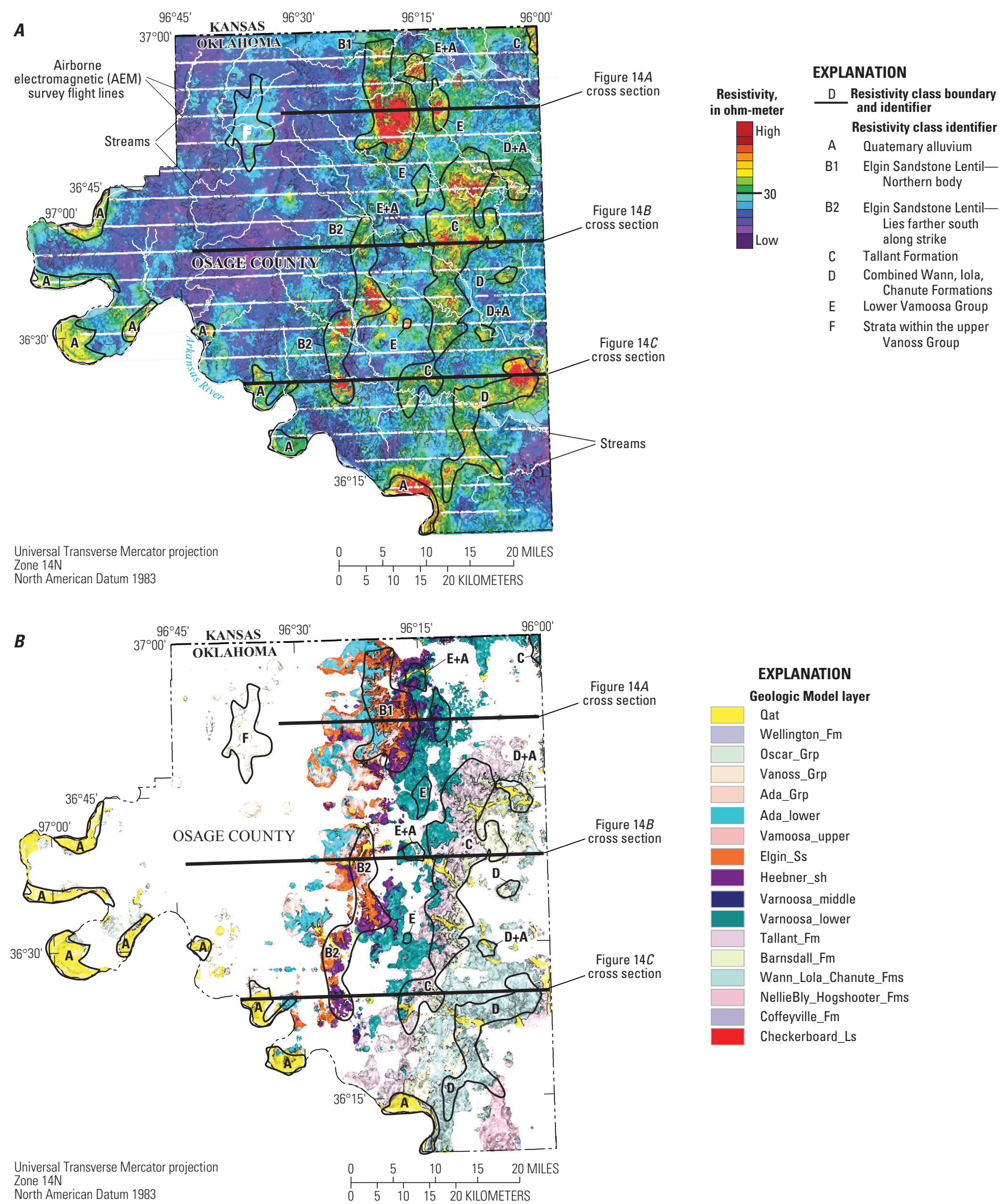

\section{EXPLANATION}

Geologic Model layer

Qat

Wellington_Fm

Oscar_Grp

Vanoss_Grp

Ada_Grp

Ada_lower

Vamoosa_upper

Elgin_Ss

Heebner_sh

Varnoosa_middle

Varnoosa_lower

Tallant_Fm

Barnsdall_Fm

Wann_Lola_Chanute_Fms

NellieBly_Hogshooter_Fms

Coffeyville_Fm

Checkerboard_Ls

Figure 13. A, Map view of integrated geology-resistivity model illustrating areas of high resistivity corresponding to possible freshwater aquifers and six (A-F) geology-electrical resistivity classes. Thin white lines are major streams and include the Arkansas River that coincides with the southwestern border of Osage County. Thick black lines show cross section locations for figure 14. $B$, Vertical view of geologic layers with electrical resistivity $>30 \mathrm{ohm}-\mathrm{m}$ with overlain geology-electrical resistivity classes. 


\section{Class A-Quaternary Alluvium}

Several high-resistivity bodies correspond to shallow Quaternary alluvium aquifers that are most prominent in the southwestern part of the county adjacent to the Arkansas River (fig. 1). The imaged bodies are discontinuous along the Arkansas River (fig. 13), but this may partly be an artifact of the northerly interpolation between flight lines of the regional AEM survey. In contrast to the north-northeast trending Paleozoic bedrock units, the meandering and dendritic body shapes of the alluvial valleys do not project linearly between the nearly east-west profiles used in the 3-D resistivity modeling. Additional processing of north-south tie lines could aid assessing the continuity of high resistivity in such meandering alluvial aquifer bodies. In some areas, zones of high resistivity associated with Quaternary deposits also extend into adjacent bedrock layers, suggesting they may be areas of bedrock recharge. For example, in the eastern part of the county several smaller high resistivity bodies coincide with but also extend into shallow bedrock underlying alluvial fills (fig. 13B).

\section{Class B-Elgin Sandstone Lentil}

A strong north-northeast trending zone of high resistivity in the central part of the county is centered on the Elgin Sandstone Lentil, but also overlaps parts of the overlying Vamoosa_upper and underlying Heebner_sh model layers (fig. 13A, B). A northern body (B1) is the largest contiguous concentration of high resistivity in the county and its core of resistivity greater than $30 \mathrm{ohm}-\mathrm{m}$ slopes shallowly westward, extending as much as $10 \mathrm{~km}$ down-dip from the surface parallel to the dip of the Elgin strata (fig. 14A). A second body (B2) lies farther south along strike.

\section{Class C-Tallant Formation}

Another large semi-continuous north-northeast trending zone of high resistivity bodies is centered on the Tallant Formation but overlaps the overlying Vamoosa_lower and underlying Barnsdall_Fm model layers. Similar to the class B Elgin-centered bodies, high-resistivity bodies associated with the Tallant Formation slope westward parallel to geologic layer dips (fig. 14B, 14C). Such high-resistivity bodies could include sandstone intervals such as the Bigheart Sandstone Member at the base of the Tallant Formation.

\section{Class D-Combined Wann, Iola, Chanute Formations}

A third band of high-resistivity bodies lies in the combined Wann_Iola_Chanute_Fms model layer. The largest body is present in the southeastern part of the county (fig. 13). Other smaller resistivity bodies coincide with where the Wann-IolaChanute_Fms model layer is overlain by Quaternary alluvial bodies, suggesting a potential freshwater recharge connection between Quaternary alluvium and the underlying bedrock.

\section{Class E-Lower Vamoosa Group}

Several small distinct high-resistivity bodies lie between the class B Elgin-centered and class C Tallant-centered bodies and coincide with middle to upper parts of the Vamoosa_lower geologic model layer (fig. 13), and like other bedrock zones extend far down dip to the west (fig. 10). Two high-resistivity bodies coincide with overlying Quaternary alluvial deposits, but others with clear elongation parallel to bedrock strike are isolated from potential Quaternary or stream recharge sources. It is likely that these high-resistivity bodies represent small sandstone or limestone lenses in the lower part of the Vamoosa Group (D’Lugosz and others, 1986).

\section{Class F-Upper Vanoss Group}

Although the bulk of the shallow bedrock in the western part of Osage County is characterized by low resistivity (fig. 13), a body of moderately high resistivity (25-35 ohm-m) coincides with topographic cuestas underlain by an interval in the upper Vanoss Group in the northwestern part of the county. Inspections of wire-line geophysical logs in this area suggest that these bodies of higher resistivity probably correspond to limestone layers that are known within the upper part of the Vanoss Group (Branson, 1957).

\section{Comparison of Electrical Resistivity to Depth to Potable Water Estimates}

In their assessment of freshwater resources in the VamoosaAda aquifer, D'Lugosz and others (1986) used geophysical logs from drill holes to estimate the depth to potable water (total dissolved solids $<1,500$ milligram/liter (mg/l)) for an area that extended through the central area of Osage County. Within Osage County, their study included two deepened troughs of potable water on eastern and northwestern sides of the studied area (fig. 15). Although a quantitative correlation between the water-quality threshold used by D'Lugosz and others (1986) and the electrical resistivity values from the AEM survey is uncertain, there is a general correspondence between the down-dip projections of the class B Elgin-centered and class C Tallant-centered, high-resistivity bodies with the lower parts of the northwestern and eastern potable water troughs, respectively (fig. 15C, $D$ ). However, rather than a hydrogeologic model in which such troughs contain groundwater with a continuous, downward increasing concentration of dissolved solids to the base of the potable water limit, the AEM model indicates that there are probably westward-inclined lenses of fresher water segregated into several different geologic horizons in such troughs. 
$\boldsymbol{A}$
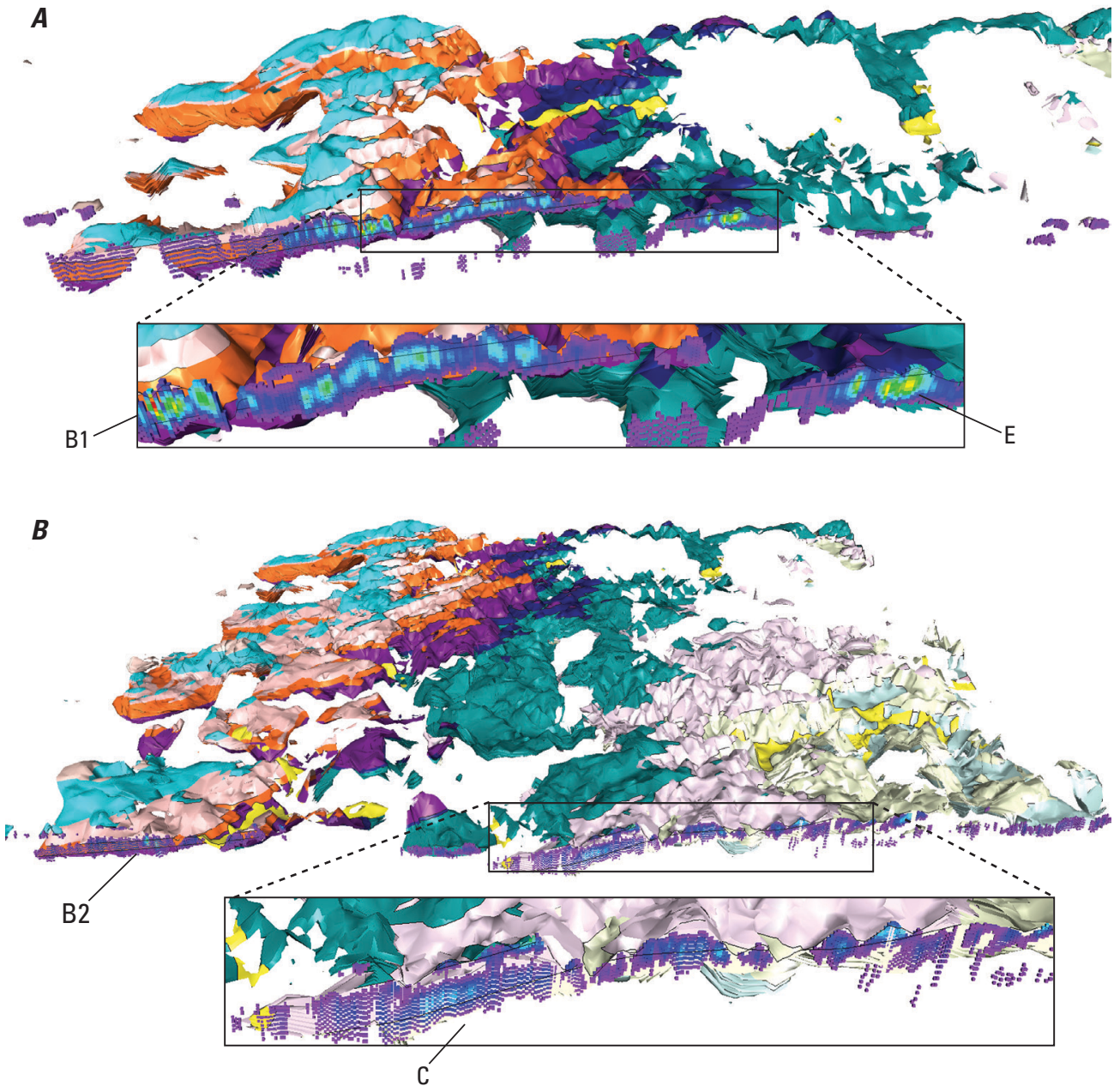

C

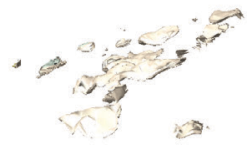

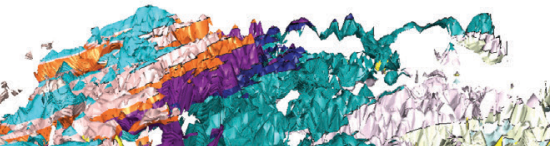

(a)
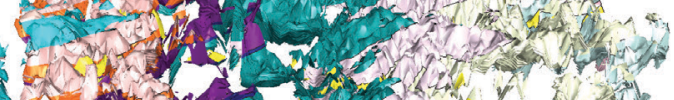

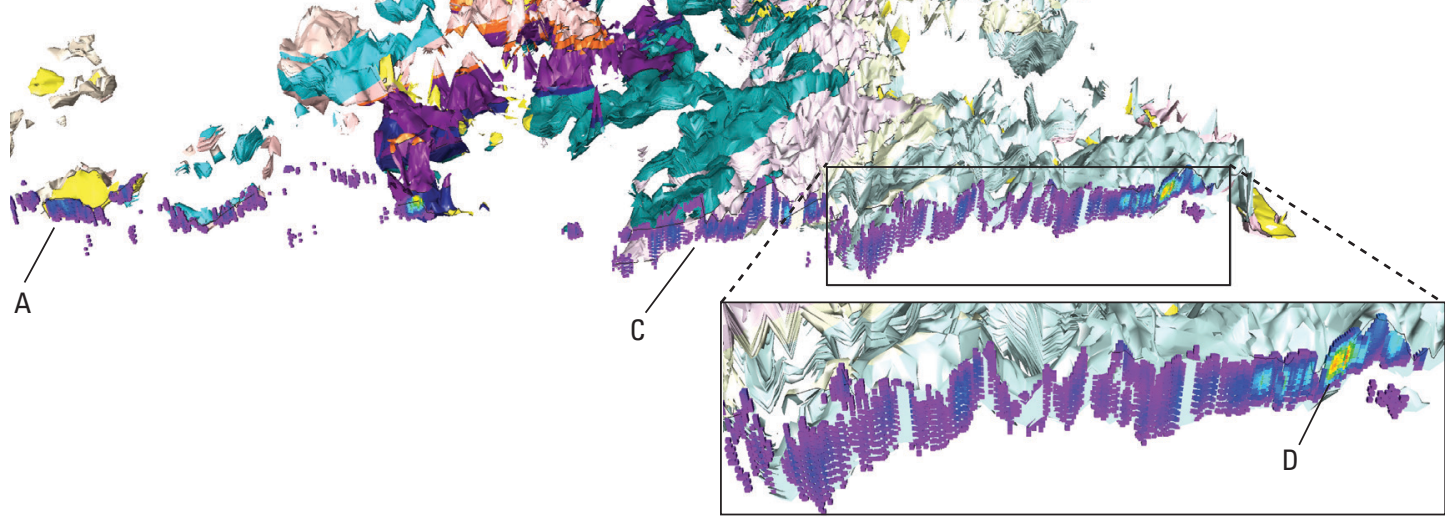

\section{EXPLANATION}

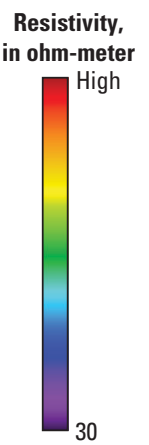

\begin{tabular}{|c|c|}
\hline \multicolumn{2}{|c|}{ Geologic Model layer } \\
\hline & Qat \\
\hline & Wellington_Fm \\
\hline & Oscar_Grp \\
\hline & Vanoss_Grp \\
\hline & Ada_Grp \\
\hline & Ada_lower \\
\hline & Vamoosa_upper \\
\hline & Elgin_Ss \\
\hline & Heebner_sh \\
\hline & Varnoosa_middle \\
\hline & Varnoosa_lower \\
\hline & Tallant_Fm \\
\hline & Barnsdall_Fm \\
\hline & Wann_Lola_Chanute_Fms \\
\hline & NellieBly_Hogshooter_Fm \\
\hline & Coffeyville_Fm \\
\hline & Checkerboard_Ls \\
\hline & asistivity class identifier \\
\hline$A$ & Quatemary alluvium \\
\hline B1 & $\begin{array}{l}\text { Elgin Sandstone Lentil- } \\
\text { Northern body }\end{array}$ \\
\hline B2 & $\begin{array}{l}\text { Elgin Sandstone Lentil- } \\
\text { Lies farther south } \\
\text { along strike }\end{array}$ \\
\hline C & Tallant Formation \\
\hline D & $\begin{array}{l}\text { Combined Wann, Iola, } \\
\text { Chanute Formations }\end{array}$ \\
\hline $\mathrm{E}$ & Lower Vamoosa Group \\
\hline
\end{tabular}

Figure 14. Perspective views of the integrated geology-resistivity model and primary data line electrical resistivity values, both showing electrical resistivity $>30 \mathrm{ohm}-\mathrm{m}$, with enlarged insets of cross section segments. Geology-electrical resistivity classes of figure 13 are labeled. $A$, Northern section illustrating correlation of high-resistivity with Elgin_Ss model layer. Legends for electrical resistivity and geologic model layer pertain to all images. $B$, Central section illustrating correlation of high resistivity with higher Elgin_Ss layer and lower Tallant_Fm model layer. C, Southern section illustrating correlation of high electrical resistivity with lowest Wann_lola_Chanute_Fms layer as well as higher layers. 


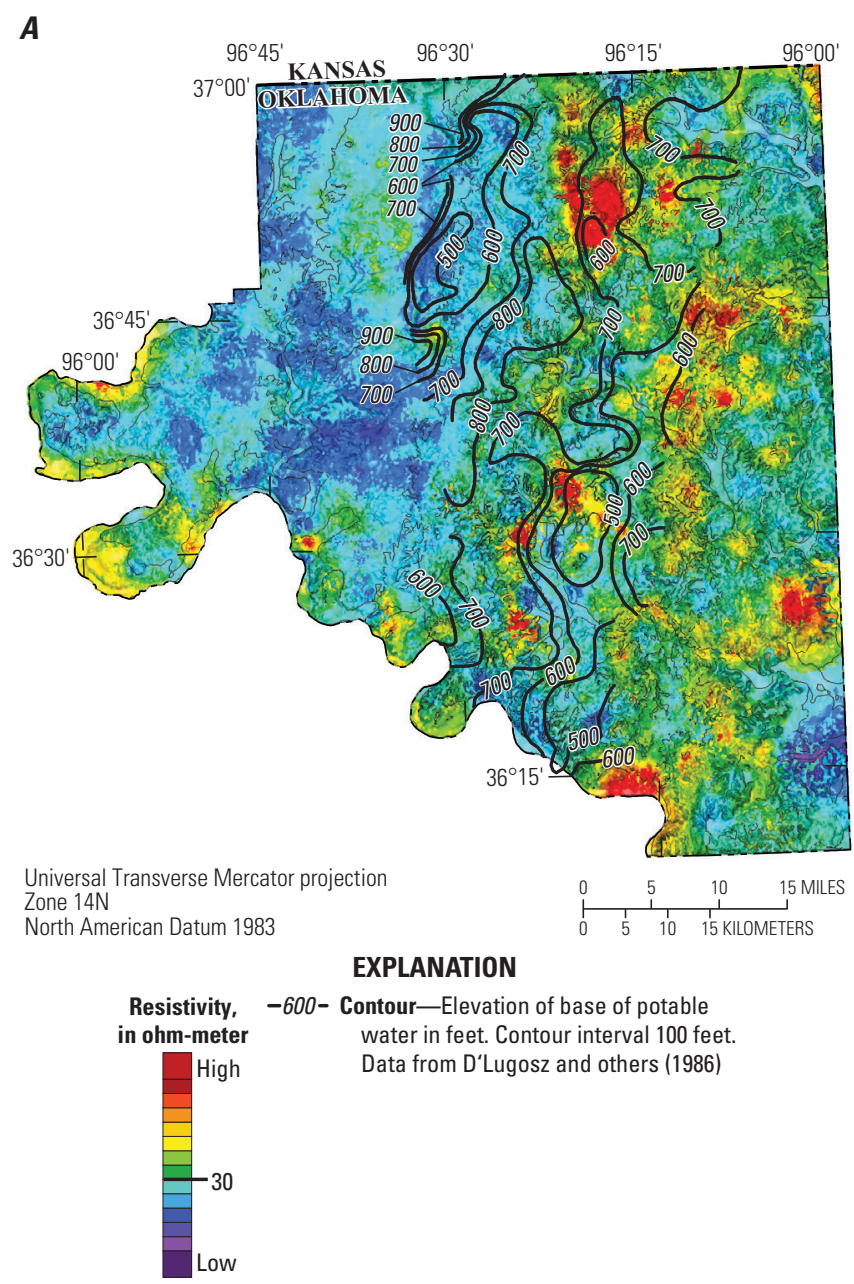

C Geologic model layer fences with resistivity greater than 30 ohm-meters (ohm-m)

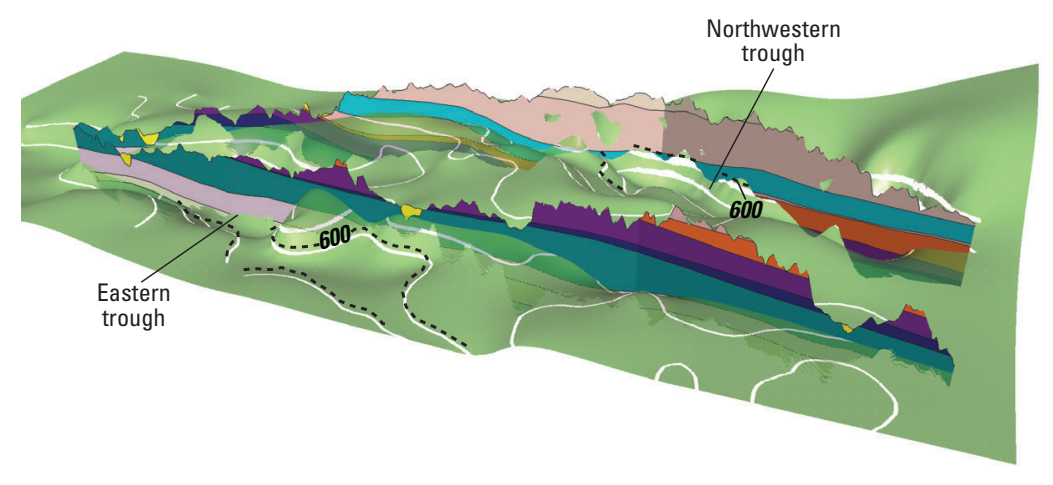

B

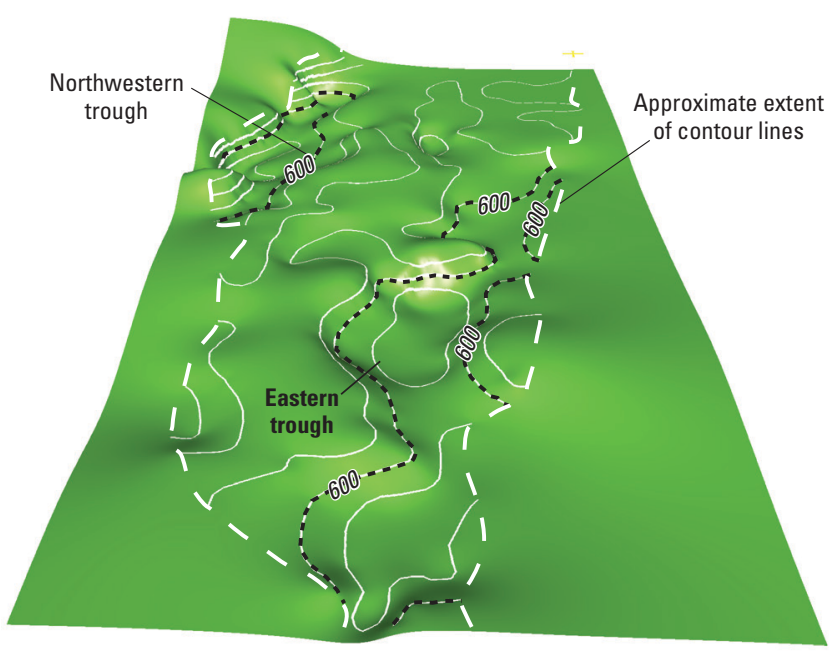

EXPLANATION

- 600- Contour-Elevation of base of potable water in feet. Contour interval 100 feet. Data from D'Lugosz and others (1986). Thin white line is intermediate contour

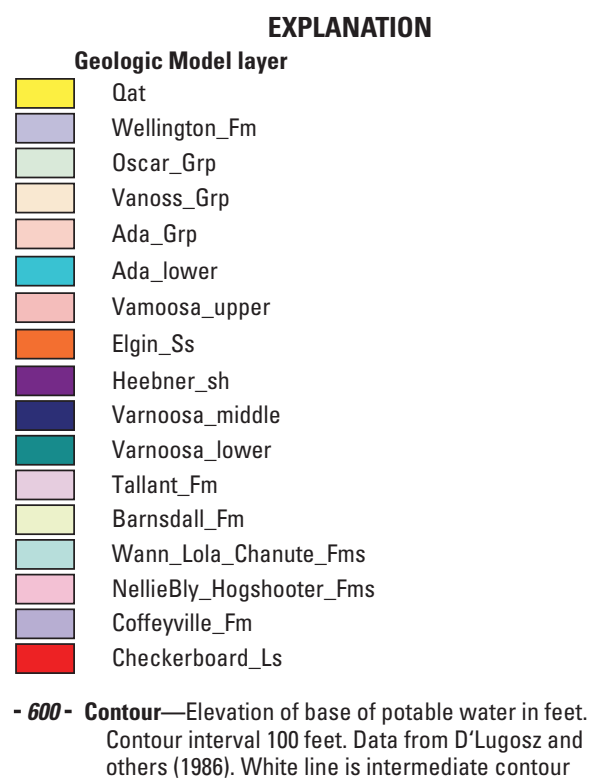

Figure 15. Base of potable water from D'Lugosz and others (1986) compared to integrated geology-resistivity model views. $A$, Map view of electrical resistivity as in figure $13 A$ with draped elevation contours ( $100 \mathrm{ft}$ contour interval) of base of potable water from D'Lugosz and others (1986), $B$, Northward perspective view of three-dimensional (3-D) model surface representing the base of the potable water with draped structure contours (thin white lines). Black dashed line at $600 \mathrm{ft}$ contour elevation outlines the eastern and northwestern troughs of the potable water base. Thick dashed white lines show approximate boundary of D'Lugosz and others' (1986) study. C, Southwestward perspective view showing a fence diagram of geologic model layers having a resistivity $>30$ ohm-m that fills the eastern and northwestern potable water troughs. 


\section{Conclusions}

Upper Pennsylvanian-Lower Permian sedimentary rocks dip gently westward beneath Osage County, and their surface outcrops and subsurface picks on wire-line geophysical logs were used to construct a 3-D model of the geologic framework as an aid in evaluating groundwater resources in the county. Quaternary alluvium and terraces along major streams and the Arkansas River are also included in the geologic framework model, using artificial data points to sculpt unconformity surfaces filled with alluvial deposits where well data were not available.

Electromagnetic geophysical data collected and documented by XRI were provided to the Osage Nation in March, 2014. This airborne electromagnetic survey (AEM) was subjected to USGS quality control and truncated at depth of investigation (DOI). It was then built into a 3-D resistivity model making use of interpolated secondary and tertiary resistivitydepth sections between primary data lines.

The AEM data show westward-inclined resistivity gradients that parallel the shallow dip of bedrock strata and several bodies with resistivity $>30 \mathrm{ohm}-\mathrm{m}$ extend as much as $10 \mathrm{~km}$ down the dip of host geologic units. Because saline waters have low resistivity and freshwater aquifers in sandstone or limestone have high resistivity (Dobrin, 1976), those layers with high proportions of high resistivity are a proxy for potential freshwater aquifers.

Volume analysis and internal imaging of the combined 3-D geology and electrical resistivity model defines the following probable aquifer units with large relative volumes of relatively high resistivity:

- Quaternary alluvium,

- Elgin Sandstone Lentil in the upper part of the Vamoosa Group,

- Tallant Formation, and parts of the combined Wann-Iola-Chanute geologic layer, and

- Lesser volume, high-resistivity bodies correspond to intervals in the lower part of the Vamoosa Group in the east-central part or the county and probable limestone intervals in the upper part of the Vanoss Group in the northwest part of the county.

Northwestern and eastern troughs of potable water defined by D'Lugosz and others (1986) for Osage County generally correspond to down-dip projections of highresistivity bodies associated with the Elgin Sandstone Lentil of the Vamoosa Group and Tallant Formation.

\section{References Cited}

Aarhus University, 2015, Aarhus-workbench: Aarhus, Denmark, Aarhus University. [Available at url: http://hgg.au.dk/ software/Aarhus-workbench/.]

Abbott, M.M., 2000, Water quality of the Quaternary and Ada-Vamoosa Aquifers on the Osage Reservation, Osage County, Oklahoma, 1997: U.S. Geological Survey WaterResources Investigations Report 99-4231, 76 p. [Also available at https://pubs.er.usgs.gov/publication/wri994231.]

Andrews, W.J., and Smith, S.J., 2014, Description of landscape features, summary of existing hydrologic data, and identification of data gaps for the Osage Nation, northeastern Oklahoma, 1890-2012: U.S. Geological Survey Scientific Investigations Report 2014-5134, 53 p., http://dx.doi.org/10.3133/sir20145134.

Auken, Esben, Christiansen, A.V., Jacobsen, B.H., Foged, Nikolaj, and Sørensen, K.I., 2005, Piecewise 1D laterally constrained inversion of resistivity data: Geophysical Prospecting, v. 53, p. 497-506.

Ball, L.B., Bloss, B.R., Bedrosian, P.A., Grauch, V.J.S., and Smith, B.D., 2015, Airborne electromagnetic and magnetic survey data of the Paradox and San Luis Valleys, Colorado: U.S. Geological Survey Open-File Report 2015-1024, 19 p., http://dx.doi.org/10.3133/ofr20151024.

Bass, N.W., 1942, Subsurface geology and oil and gas resources of Osage county, Oklahoma, Part II, Summary of subsurface geology with special reference to oil and gas: U.S. Geological Survey Bulletin 900-K, p. 343-393. [Also available at https://pubs.er.usgs.gov/publication/b900K.]

Beckwith, H.T., 1928, Geology of Osage County: Oklahoma Geological Survey Bulletin 40-T, 63 p.

Bedrosian, P.A., Ball, L.B., and Bloss, B.R., 2014, Airborne electromagnetic data and processing within Leach Lake Basin, Fort Irwin, California, chap. G of Buesch, D.C., ed., Geology and geophysics applied to groundwater hydrology at Fort Irwin, California: U.S. Geological Survey Open File Report 2013-1024, 20 p., http://dx.doi.org/10.3133/ ofr20131024G.

Bingham, R.H., and Bergman, D.L., 1980, Reconnaissance of the water resources of the Enid Quadrangle north-central Oklahoma: Oklahoma Geological Survey, Hydrologic Atlas 7, 4 sheets.

Boyd, D.T., 2011, J.Glenn Cole-A stratigraphic legacy preserved: Shale Shaker, May/June, p. 329-336. 
Branson, C.C., 1957, Oklahoma facies of Kansas Formations, in Field Conference in Eastern Kansas, Jewett, J.M., and Muilenburg, Grace, eds., 21st field conference, Sept. 19-21: Kansas Geological Society and the State Geological Survey of Kansas Guidebook, p. 92-104.

Brown, S.L., 1967, Stratigraphy and depositional environment of the Elgin Sandstone (Pennsylvanian) in south-central Kansas: Kansas Geological Survey Bulletin 187, part 3, p. 1-12.

Cole, J.G., 1967, Regional stratigraphy of the Marmaton Group of northeastern Oklahoma: Shale Shaker Digest V, v. 17, p. $112-123$.

Cole, J.G., 1969, Cherokee Group, east flank of the Nemaha Ridge, north-central Oklahoma: Shale Shaker, v. 19, p. 134-146.

D’Lugosz, J.J., McClaflin, R.G., and Marcher, M.V., 1986, Geohydrology of the Vamoosa-Ada aquifer east central Oklahoma: Oklahoma Geological Survey Circular 87, 42 p.

Danielsen, J.E., Auken, Esben, Jørgensen, Flemming, Søndergaard, Verner, and Sørensen, K.I., 2003, The application of the transient electromagnetic method in hydrogeophysical surveys: Journal of Applied Geophysics, v. 53, no. 4, p. 181-198.

Dobrin, M.B., 1976, Introduction to Geophysical Prospecting (3d. ed.): McGraw-Hill, 630 p.

Energy Libraries Online, 2015, J. Glenn Cole memorial crosssection collection: Oklahoma City Geological Society, accessed June 19, 2015, at http://www.energylibrariesonline.com/ GlennColeMenu.aspx.

Dynamic Graphics, Inc, 2015, EarthVision, v. 9.0: Alameda, Calif., Dynamic Graphics, Inc. [Also available at http://www.dgi.com/earthvision/evmain.html.]

Fay, R.O., 1997, Stratigraphic units in Oklahoma, Texas, Arkansas, and adjacent areas: Oklahoma Geological Survey Open-File Report 2-97, 229 p., 4 pl. [Also available at http://www.ou.edu/ content/ogs/publications/openfilereports.html.]

Fitterman, D.V., and Labson, V.F., 2005, Electromagnetic induction methods for environmental problems, in Butler, D.K. ed., Near-surface geophysics: Society of Exploration Geophysicists Books, Investigations in Geophysics series, no. 13 , p. 301-355.

Foley, L.L., 1926, The origin of faults in Creek and Osage Counties, Oklahoma: American Association of Petroleum Geologists Bulletin, v. 10, p. 293-303.

Gentile, R.J., and Thompson, T.L., 2004, Paleozoic succession in Missouri, part 5, Pennsylvania Subsystem: Missouri Department of Natural Resources, Division of Geology and Land Survey, Report of Investigations 70, 1 CD ROM. [Accompanied by Gentile R.J., Thompson, T.L., and Mulvany, P.S., 2004, The Pennsylvanian System; Comparison of former and present classifications: Missouri Department of Natural Resources, Division of Geology and Land Survey, 1 chart.]
Heran, W.D., Green, G.N., and Stoeser, D.B., 2003, A digital geologic map database for the state of Oklahoma: U.S. Geological Survey Open-File Report 03-247. [Also available at https://pubs.er.usgs.gov/publication/ofr03247.]

Johnson, C.L., 1992, Burbank Field-U.S.A. Anadarko Basin, Oklahoma: American Association of Petroleum Geologists Treatise, Stratigraphic Traps III, p. 333-345.

Keller, G.V., 1987, Rock and mineral properties, in Nabighian, M.N., ed., Electromagnetic methods in applied geophysics theory: Tulsa, Okla., Society of Exploration Geophysicists, v. 1, p. $13-51$

Keller, G.V., 1989, Electrical properties, in Carmichael, R.S., ed., Practical handbook of physical properties of rocks and minerals: Boca Raton, Fla., CRC Press, p. 359-427.

Marshak, Stephen, Nelson, W.J., and McBride, J.H., 2003, Phanerozoic strike-slip faulting in the continental interior platform of the United States: examples from the Larmide Orogen, Midcontinent, and Ancestral Rocky Mountains, in Storti, F., Holdsworth, R.E., and Salvani, R., eds, Intraplate Strike-Slip Deformation Belts: Geological Society of London Special Publications, v. 210, p. 154-184.

Mashburn, S.L., Cope, C.C., and Abbott, M.M., 2003, Aquifer characteristics, water availability, and water quality of the Quaternary aquifer, Osage County, Northeastern Oklahoma, 2001-2002: U.S. Geological Survey Water-Resources Investigations Report 03-4234, 41 p. [Also available at https://pubs.er.usgs.gov/publication/wri034235.]

Nabighian, M.N., and Macnae, J.C., 1991, Time-domain electromagnetic prospecting methods, in Nabighian, M.N., ed., Electromagnetic methods in applied geophysics: Society of Exploration Geophysicists Books, Investigations in Geophysics no. 3, v. 2, p. 427-520.

Sawin, R.S., West, R.R., Franseen, E.K., Watney, W.L., and McCauley, J.R., 2006, Carboniferous-Permian boundary in Kansas, Midcontinent, U.S.A., in Current research in Earth sciences: Kansas Geological Survey Bulletin 252, part 2, accessed Feb. 21, 2016 at http://www.kgs.ku.edu/ Current/2006/sawin/index.html.

Sawin, R.S., Franseen, E.K., West, R.R., Ludvigson, G.A., and Watney, W.L., 2008, Clarification and Changes in Permian Stratigraphic Nomenclature in Kansas: Kansas Geological Survey, Current Research in Earth Sciences, Bulletin 254, part 2. [Also available at http://www.kgs.ku.edu/ Current/2008/Sawin/index.html.]

Shields, R.H., Jr., 1993, A water resources management strategy for surface and groundwater in Osage County, Oklahoma utilized to formulate policy guidelines for water rights and resources protection and management for Indian lands: Stillwater, Oklahoma State University, Ph.D. dissertation, 161 p.

Tanner, W.F., 1956, Geology of northeastern Osage County, Oklahoma: Oklahoma Geological Survey Circular 40, 76 p., 4 pl. (including geologic map). [Also available at http://www.ou.edu/content/ogs/publications/circulars.html.] 


\section{Appendix}

The 3-D geologic model constructed for Osage County, Okla. consists of 17 separate layers. To facilitate use of the layers for other purposes, such as construction of a groundwater flow model, structure contours (10 $\mathrm{m}$ interval) for each were exported as shapefiles.

To run program on local system, minimally copy executable files (.exe), faces files (.enc.faces), and optionally, other data or image files to a local directory. The model was created using version 9.0 of the software. We suggest using the included zone (Osage_1_Custom.znclr) and property (property.pclr) files to help match model colors to report. Color settings are found in the color menu, hot key 9. The property color settings "Color start" should be 62, the property color setting "Color step" should be set at 4. Refer to "QuickHelp.pdf" in the "Help" directory for brief instructions to start and run software. 
Publishing support provided by:

Denver Publishing Service Center, Denver, Colorado

For more information concerning this publication, contact:

Center Director, USGS Geosciences and Environmental Change Science Center

Box 25046, Mail Stop 980

Denver, C0 80225

(303) 236-5344

Or visit the Geosciences and Environmental Change Science Center at: http://gec.cr.usgs.gov/

This publication is available online at: http://dx.doi.org/10.3133/sir20165067 
